\title{
Çocuk Bakımında Büyükannelik ve Büyükbabalık: Toplumsal Cinsiyet Tartışmaları Bağlamında Nitel Bir Araştırma
}

\author{
Sinem Burcu UGUR ${ }^{1^{*}}$ \\ ${ }^{1}$ Dr., Orcid id: 0000-0002-4984-4015
}

Geliş Tarihi/Received: 25.02.2019

Kabul Tarihi/Accepted: 27.02.2019
Doi: dx.doi.org/10.31200/makuubd.532016

Araştırma Makalesi/Research Article

\section{ÖZET}

1970'lerde başlayan teknolojik, ekonomik, demografik, kültürel ve politik değişiklikler dünyanın bütün ülkelerinde gerek biçimsel gerek yapısal, köklü dönüşümlere yol açmıştır. Bu değişimler, aile kurumunu da etkilemiştir. Aile yapılanmasında gözlenen belirgin dönüşümlerden biri, büyük ebeveynliğin çocuk bakım sorumluluğunu da içeren bir rol olarak konumlanır hale gelmiş olmasıdır. Çağdaş dünyada büyük ebeveynliğin çocuk bakım ihtiyacına da cevap veren bir role dönüşmesi, boşanmış, tek ebeveynli ailelerin 1980'lerden itibaren dünya çapında yaygınlaşmasına ek olarak artan kadın istihdamından kaynaklanmaktadır. Bu gelişmelerin yanı sıra ortalama ömrün uzamasıyla, torun bakım sorumluluğunun da dahil olduğu yeni büyük ebeveynlik rolü, uzun soluklu bir hal almaktadır. Ne var ki bakım sürecine aktif katılım kültürel normlar, cinsiyet rolü özellikleri ve erkek ile kadın rollerinin geleneksel görünüşleri doğrultusunda biçimlendiği için büyükanne-babaların bakım faaliyetine katılım dereceleri ve bakıma ilişkin üstlendikleri sorumluluklar, farklılaşmaktadır. Ancak büyük ebeveyn-torun ilişkisi üzerine yapılan araştırmaların büyük kısmında büyükbabalar çok küçük bir örneklem içinde yer almaktadır. Kendi büyük ebeveynlik deneyimleri büyük ebeveynlik literatüründe sınırlı yer bulabilen büyükbabalara ilişkin veriler, yoğunluklu olarak büyükannelere ait bulgular olarak rapor edilmektedir. Bu bakımdan bu makalede, ailenin yapılanmasında değişikliklere yol açan eğilimlerin sonucunda ortaya çıkan torun bakım ihtiyacına büyükannelerin yanı sıra büyükbabaların ne denli katılım gösterdiklerinin ve bu süreçte hangi rolleri üstlendiklerinin incelenmesi amaçlanmaktadır. Büyük ebeveynlerle gerçekleştirilen görüşmeler neticesinde torunların fiziksel bakım ihtiyaçlarının büyükannelerince karşılandığı, büyükbabaların da torunlarının araçsal ihtiyaçlarına cevap verme konusunda daha fazla sorumluluk aldıkları anlaşılmışırı. 
Anahtar kelimeler: Büyük Ebeveynlik, Çocuk Yetiştirme, Toplumsal Cinsiyet Rolleri, Bakım Pratikleri.

\title{
Grand Maternity and Grand Paternity in Child Care: A Qualitative Study in the Context of Gender Discussions
}

\begin{abstract}
The technological, economic, demographic, cultural and political changes that started in the 1970s led to formal and structural transformations in all countries of the world. These changes also affected the family institution. One of the significant transformations in the family structure is that grandparenting has become a role, including the responsibility of child care. In the contemporary world, the transformation of grandparenting into a role that responds to the need for child care, is due to increased female employment as well as the spread of divorced and single-parent families worldwide since the 1980s. In addition to these developments, the prolonged life span makes the new grandparenting roles, which henceforth include grandchild care responsibility, last longer. However, active participation in the care process is shaped by cultural norms, gender role characteristics and traditional aspects of male and female roles. Therefore, the degree of participation of grandmothers and grandfathers in care activities and their responsibilities for care are different. However, the majority of research on the relationship between grandparents and grandchildren, grandfathers are not focal point. They are included in a very small sample. Data on grandfathers, whose grandparenting experiences are limited in the grandparenting literature, have been reported as findings from grandmothers.
\end{abstract}

In this regard, the aim of this article is to examine the extent to which grandmothers and grandfathers participate in grandchild care needs. The article also aims to reveal the roles that grandmothers and grandfathers undertake in the grandchild care process. Through the interviews with grandparents, it was understood that the grandchildren's physical care needs were met by their grandmothers and that grandfathers took more responsibility to meet the instrumental needs of their grandchildren.

Keywords: Grandparenting, Child Rearing, Gender Roles, Care Practices. 


\section{GíRiş}

Aile içinde yaşlilar için en yaygın sosyal rollerden biri olan büyük ebeveynlik, torunların dünyaya gelmesiyle kazanılan sosyal bir statüdür. Aile içinde büyükanne-baba ve torun(lar) arasındaki ilişkileri ifade eden büyük ebeveynlik, üç veya daha fazla neslin varlığını sürdürdüğünün bir göstergesidir.

Çoğunlukla yaşamın ilerleyen dönemlerinde edinilen bir rol olan büyük ebeveynliğin doğası toplumsal, ailevi, sosyal ve kültürel faktörlerce şekillenmektedir. Bunun yanı sıra büyük ebeveyn-yetişkin çocuk-torun ilişkilerinin üçlü doğası ve bunların aile uygulamaları içerisinde ortaya konulma biçimleri, büyük ebeveynliği şekillendirmektedir (Timonen ve Arber, 2012: 1-2). Büyük ebeveynler kişisel durumlarına ve tercihlerine bağlı olarak da kendi büyükanne-babalık tarzlarını müzakere edip geliştirmektedirler (Herlofson ve Hagestad, 2012: 27-28). Bu bakımdan farklı toplumsal ve ailevi bağlamlardaki kadın ve erkeklerin büyük ebeveynlik rollerini gerçekleştirmeleri birbirlerinden farklıdır. Nitekim büyük ebeveynlik rolleri, büyük ebeveynliğin kapsamı ve anlamına ilişkin yürütülen çalışmalar büyük ebeveynlik stilinin/tarzının kişiden kişiye, büyük ebeveynlerin ömrü boyunca ve torunların ömrü boyunca farklılaştı̆̆ını ortaya koymuştur (Baydar ve Brooks-Gunn, 1998: 385). Tüm bu farklılıklarıyla birlikte, büyük ebeveynlerin aile içinde toruna ilişkin rolleri belli başlı eylemleri içermektedir. Birlikte eğlenme, televizyon izleme, günlük geziler düzenleme, dini aktivitelere katılma, çocuğa yeni bir yetenek ya da oyunu öğretme, tavsiyelerde bulunma, harçlık sağlama, çocuğun problemlerini tartışma ve ebeveyn ile çocuk arasında arabuluculuk yapma gibi etkinlikler, büyük ebeveynlerin torunlarıyla direkt ilişkilerinde sıklıkla yer aldıkları aktivitelerdir (Denham ve Smith, 1989: 346-347). Bunların yanı sıra yaşanan ailevi krizlerde (hastalık veya boşanma gibi) torunlarca yararlanılabilir olmak, çocukların ve ailelerinin ekonomik güvenliğine katkıda bulunmak, torunlarına bakım sağlayan büyük ebeveyn davranışlarına ilişkin beklentilerden bazılarını oluşturmaktadır (Herlofson ve Hagestad, 2012: 31-32). Büyük ebeveynler ayrıca değerleri, kültürel mirası ve aile geleneklerini torunlarına anlatarak torunlarında ailevi ve de tarihsel bir bilinç uyandırırlar (Schmid, 2018: 59). Bu yaygın rolleri aracılığıyla büyük ebeveynler, torunlarının yetiştirilmesinde ve kişiliklerinin gelişmesinde önemli kaynakları oluştururlar (Arpacı ve Tezel Şahin, 2015: 234). Ancak yirminci yüzyılın sonlarından itibaren küresel düzeyde tanıklık edilen çok boyutlu değişiklikler, büyük ebeveynlerin aile içinde torunlarına ilişkin daha fazla roller üstlenmelerine ve hatta torun bakım faaliyetine daha aktif katılımlarına yol açmıştır (Timonen ve Arber, 2012: 1). 
Büyük ebeveynlerin torun bakımı faaliyetine dahil olup, orta kuşak ebeveynlerin ihtiyaç duydukları bakım desteğini sağlamaları yaygın bir gelenek oluşturmaktadır. Ne var ki ABD, Afrika ve Asya ülkelerinde oldukça popüler olan ve giderek dünya çapında da yaygınlaşan boşanma, sık eş değiştirme, tek ebeveynlik gibi yeni aile görünümlerinin yanı sıra orta kuşakta yaşanan madde bağımlılı̆̆ı, kronik fiziksel/zihinsel hastalıklar, ölüm, tutukluluk hali, çocuk istismarı gibi ailesel krizler, büyük ebeveynleri torunlarının bakımını sağlayan yegane kaynaklara dönüştürmektedir (Richards ve Harris, 2001: 68; Goodman ve Silverstein, 2001: 566; Wang ve Marcotte, 2007: 1; Kemp, 2007: 858; Williams, 2011: 959; Choi vd., 2016: 120). Özellikle boşanma veya ölüm gibi ailesel krizlerin yaşandığı durumlarda büyük ebeveynler bakım ve korunmaya muhtaç çocukların birincil bakımını üstlenmekte, torunları için ebeveynlik rolünü tekrar yerine getirebilmektedir (Kemp, 2007: 858; Mehta ve Thang, 2012: 2-3; Villar vd., 2010: 282). Söz konusu ekonomik ve sosyal değişiklikler birincil bakım sorumluluğunu tek başlarına üstlenmelerini gerektirmese de bu kriz dönemlerinde çocukları ve torunları için önemli bir finansal, araçsal ve duygusal destek kaynağı oluşturmaktadırlar (Timonen ve Arber, 2012: 5-6; Villar vd., 2010: 282).

Büyük ebeveynlerin torun bakım faaliyetinde daha etkin olmalarının ardında yatan dinamiklerden bir diğeri, kadınların giderek artan oranda istihdamda yer almalarıdır. Çift çalışanlı ailelerin yaygınlığı, birçok büyükanne ve büyükbabanın düzenli veya düzensiz olarak torunlarının bakımında görev almalarına yol açmaktadır (Mehta ve Thang, 2012: 12-13; Herlofson ve Hagestad, 2012: 42; Timonen ve Arber, 2012: 6-7). Bu bağlamda aile yapılanmasının büyük ebeveynlerin aile içindeki konumlarını etkilediği ve bu konumlarıyla bağlantılı olarak bakım sürecinde farklı roller oynadıkları belirtilebilir.

Aile hayatının geçirdiği bu dönüşümlerin yanı sıra demografik alanda yaşanan gelişmeler de ayrıca büyük ebeveynlerin torun bakım faaliyetine katılım düzeylerine etki ederek bakım bağlamında büyük ebeveynliği şekillendirir. Özellikle gelişmiş ülkelerde sağlık alanındaki ilerlemeler neticesinde ömrün uzaması ve yaşam kalitesinin yükselmesiyle, yetişkinlerin büyük çoğunluğunun yetişkinliklerinin en az dörtte birini büyük ebeveyn olarak geçirmeleri olası hale gelmiştir (Gauthier, 2002; Clarke ve Roberts; 2004; Dellmann-Jenkins vd., 2005; Griggs vd., 2010; Margolis, 2016). Ortalama yaşam süresinin uzamas1, torunlarından en azından birkaçıyla daha uzun bir ömrü paylaşabilen büyük ebeveynlerin yaygınlığını artırmıştır (Armstrong, 2005: 10). Aile yaşantısına ilişkin küresel düzeyde tanıklık edilen bu dönüşümler neticesinde 20. yüzyılın sonlarından itibaren büyük ebeveynlik, çocuk bakım sorumluluğunu da içeren bir rol haline gelmiş, uzun ömürlülük ve sağlık 
koşullarındaki artışla birlikte de bu rolün daha aktif ve uzun süreli oynanması söz konusu olmuştur.

\section{BAKIM FAALIYYETININ TOPLUMSAL CINSIYYETE GÖRE ŞEKILLENMESİ}

Çocuk bakımı sağlama ve pek çok koşulda torunlarının bakım sağlayıcıları olarak konumlanma, büyük ebeveynlik rolünün içerdiği temel sorumlulukların başlıcalarıdır. Bununla birlikte, toplumsal cinsiyet ilişkileri üzerine kültürel normlar, cinsiyet rolü özellikleri ve erkek ile kadın rollerinin geleneksel görünüşleri gibi faktörler, büyükanne-babaların bakıma dahil olma derecelerini ve bakım sürecinde hangi rolleri oynayacaklarını şekillendirmektedir.

Geleneksel olarak kadınla ve erkekle ilişkili olduğu kabul edilen rolleri ifade etmekte kullanılan toplumsal cinsiyet rolleri, aile içinde erkekler ve kadınların rollerini birbirinden ayırmıştır. Cinsiyete bağlı ailesel roller kapsamında toplumla bağ kurma (araçsal) rolü erkeğe/babaya aitken; aile içinde anlamlı roller ise kadınlar/anne ile ilişkilendirilmiştir. Aile içinde erkeğin en önemli rolü, ailenin maddi gereksinimlerini sağlamak ve eve ekmek getirmektir. Buna karşılık kadınlar, ev işlerinin düzenli bir şekilde yapılmasından ve çocukların bakımından sorumludur (Parsons, 1972: 140) Kadınlar ve erkekler için toplumsal olarak belirlenmiş olan mevcut cinsiyet rolleri, büyük ebeveynler söz konusu olduğunda da geçerlidir. Büyük ebeveynin cinsiyeti, büyük ebeveyn davranışlarına ilişkin beklentilerin ne ölçüde karşılanacağını/nasıl sahneleneceğini şekillendirmektedir. Dolayısıyla büyük ebeveynlerin torunlarıyla ilişkilerinin, cinsiyete bağlı ailesel rolleri bağlamında geliştiği ifade edilebilir.

Büyükanne ve büyükbabalar, kendilerine ihtiyaç duyulduğunda torunların yanında bulunma ve ebeveynlik rolünde yetişkin çocuklarına destek sağlama konusunda benzer tutumlar sergilemektedirler. Ancak, özellikle bakım faaliyeti yoğun ve düzenli bir nitelik kazandığında, büyükanne-baba çiftlerinin toruna ilişkin üstlendikleri roller farklılaştırmaktadır. Armstrong büyükbabaların aile dışı alanlardaki görev odaklı katılımlarını vurgularken (2005: 10); Herlofson ve Hagestad, büyükbabaların çocukların ve ailelerinin ekonomik güvenliğine katkıda bulunma konusunda daha çok sorumluluk aldıklarını belirterek Armstrong'u desteklemektedir. Aile içinde anlamlı roller ile ilişkilendirilmiş olan büyükannelerin aksine büyükbabalar, tıpkı babalar gibi, araçsal konularla daha fazla ilgilidir (2012: 32). Bates büyükbabaların torun bakım faaliyeti kapsamında üstlendikleri araçsal rolleri; soy ve aile kimliği kazandırma çalışmaları, eğitsel ve dini rehberlik, boş zamanların 
değerlendirilmesine ve gelecek planlamasına yönelik çalışmalar olarak sınıflandırmıştır (2009: 334-335). Büyükbabaların torunları için üstlendikleri bu roller, büyükbabalık rolünün “aileye ilişkin en önemli rolü, ailenin maddi gereksinimlerini sağlamak, eve ekmek getirmek ve araçsal ihtiyaçlara cevap vermek" biçiminde kabul gören erkeklik rolü doğrultusunda şekillendiğine işaret etmektedir.

Diğer yandan torunların ihtiyaç duyduğu sosyal bakım ve desteğin öznesini büyükanneler oluşturmaktadır. Toplumların çoğunda torunların sosyalizasyonu konusunda anahtar katılımc1lar olarak konumlanan büyükanneler, özellikle torunun ebeveynleri olan orta kuşak ile yakın oturma düzenine sahip olduklarında torunlarının bakımına daha çok dahil olmaktadırlar (Armstrong, 2005: 10). Kendilerine ihtiyaç duyulduğunda bakım desteği sağlama konusunda büyükannelerin büyükbabalara kıyasla daha istekli olmaları ve daha özverili davranmalarının (Arpacı ve Tezel Şahin, 2015: 243) temelinde, çoğu toplumda kadınların aile/akrabalık muhafızları gibi davranmak üzere toplumsallaştırılmaları yatmaktadır (Timonen ve Arber, 2012: 8). Akrabalık koruyuculuğu bilinciyle yetiştirilen büyükanneler, bakım konusunda daha fazla sorumluluk üstlenirken, bakım faaliyetine etkin katılımlarının doğal bir sonucu olarak da torunlarla büyükbabalara kıyasla daha yakın ilişkiler geliştirirler. Torunlarla kurulan yakın duygusal bağlar da ayrıca büyükannelerin çocuklarının destek ihtiyacına cevap vermeye gönüllülük göstermesinde etkili olmaktadır (Danielsbacka vd., 2015: 893; Xu vd., 2014: 229; Svensson-Dianellou vd., 2010: 260). Bu bak1mdan büyükannelerin torunlarıyla yakın ilişkiler geliştirmesinin bakımın bir sonucu olabileceği gibi, bakım sağlanmasında etken olarak da hizmet ettiği ifade edilebilir. Gerek torunlarıyla kurdukları yakın ilişkileri, gerekse de torunlarının fiziksel bakım ihtiyaçlarına cevap verme eğilimleri, büyükannelerin doyurucu ve sevgi gereksinimini karşılayıcı "kadınlık rollerini" yerine getirdiğine işaret etmektedir.

\section{ARASTTIRMA TASARIMI}

Aile yapılanmasının birkaç on yıl içinde geçirdiği radikal dönüşümler, aile içi ilişkilerde olduğu kadar görev ve sorumluluklarda da değişikliklere yol açmıştır. Küresel düzeyde tanıklık edilen yeni aile görünümleri, giderek yaygınlaşan boşanmalar ve tek ebeveynlik gibi dünya çapında yaşanan dönüşümler, aile içinde çocuk bakım organizasyonunu da etkileyerek büyük ebeveynleri çocuk bakım faaliyetinin bir parçası haline getirmiştir. Boşanma, genç gebelik, ebeveynlerden birinin ölümü veya tutukluluk hali, sık eş değiştirme gibi nedenlerle çocuklarına etkili ebeveynlik yapmakta başarısız olan orta kuşağın ihtiyaç 
duyduğu bakım desteğini sunan büyük ebeveynler, ayrıca çalışan anneleri desteklemek amacıyla da torun bakım faaliyetini üstlenmektedirler. Bir başka söylemle, orta kuşak kadınlarının istihdam oranlarının giderek artması ve günden güne daha sık rastlanır hale gelen yeni aile görünümleri, büyük ebeveynliği çocuk bakım sorumluluğunu içeren bir rol olarak şekillenmektedir. Üstelik sağlık teknolojisi ve tıp alanındaki gelişmeler sonucu ortalama yaşam süresinin artmasıyla büyükanne-babaların yeni görevlerle tanımlı büyük ebeveynlik rollerini daha uzun yıllar sürdürmeleri söz konusudur. Son 40 yılda yaşanan sert dönüşümler büyük ebeveynlerin torun bakım faaliyetine daha çok dahil olmalarıyla sonuçlanırken, bu bakımın kapsamına ilişkin değerlendirmeler ve üstlenilen sorumluluklar büyükanne-babalar arasında farklılık göstermektedir. Ne var ki, torunların bakım faaliyeti üzerine yürütülen çalışmaların daha çok büyükanneler örneklemiyle gerçekleştirilmiş olması, büyükbabaların bakım sürecine ne derece katılım gösterdiklerinin anlaşılmasına engel olmuştur. Bu bağlamda torunlarının bakım faaliyetini üstlenen büyük ebeveynlerle yapılan bu çalışmada, orta kuşağın ihtiyaç duyduğu çocuk bakım desteğine büyükanneler kadar büyükbabaların da katılım düzeylerini ortaya koymak amaçlanmıştır. Torunların bakım ihtiyacını yaratan koşullar belirlendikten sonra, büyükanne ve babaların bu ihtiyaca cevaben hangi görevleri üstlendiklerinin anlaşılması hedeflenmiştir. Torunlarının bakım sürecine dahil olan büyükanne-babaların bakıma ilişkin farklılaşan deneyimlerinin ayrıntılı bir biçimde karşılaştırılmasına olanak tanıması ve çiftlerin bu deneyimlerine ilişkin değerlendirmelerini yansıtabilmesi bakımından niteliksel yöntem tercih edilmiştir.

Örneklem, araştırmanın amacına uygun olacak şekilde torunlarının bakım ihtiyacına cevap veren ve bakım sürecine çeşitli yoğunluklarda dahil olabilen büyük ebeveyn çiftlerinden oluşmaktadır. Araştırmaya katılacak büyük ebeveynlerin seçimi olasılıklı olmayan örnekleme türlerinden biri olan kartopu örnekleme tekniği ile sağlanmıştır. Kartopu örneklemenin uygulanmasında hedefin tanımlanıp örneklemin başlatılması ve referans zincirlerinin oluşturulması aşamaları izlenerek, Antalya ilinde ailelerin değişik yoğunluklarda ihtiyaç duyduğu çocuk bakım desteğini sunan ve çalışmada yer almaya gönüllülük gösteren büyük ebeveynler araştırmaya dahil edilmiştir. Ayrıca ulaşılan kişilerin benzer özellikler barındırması riskini bertaraf etmek için farklı kartopları oluşturulmuştur.

Torunlarına bakım sağlayan büyük ebeveynlerin bakım faaliyetine ilişkin deneyimlerinin bütün yönleriyle anlaşılabilmesi için, verilerin toplanmasında "derinlemesine görüşme" tekniği tercih edilmiştir. Beklentiler, roller ve aile içi görevlere ilişkin farklılıkların ortaya konulabilmesi için büyükanne-büyükbabalarla öznel deneyimlerine odaklanan ayrı ayrı 
görüşmeler gerçekleştirilmiştir. Bu bağlamda örneklem, Antalya ilinde torun bakımına çeşitli yoğunluklarda dahil olan 20 büyük ebeveyn çiftinden oluşmaktadır. Yapılan derinlemesine görüşmeler 2019 yılının Ocak ve Şubat aylarında, katılımcı büyük ebeveynlerin evlerinde, kendi günlük ortamları içinde gerçekleştirilmiştir. En az 30 dakika ile en fazla 80 dakika süren görüşmelerin bakım sağlanan çocukların evde olmadığı zaman dilimlerinde ve baş başa yapılmasına özen gösterilmiştir.

\section{ALANDA ELDE EDÍLEN VERILLERIN SUNULUŞU}

\subsection{Demografik Özellikler}

\subsubsection{Bakım sağlanan torun sayısı}

Torun bakımı sağlayan büyük ebeveynlerin sahip oldukları torun sayısının belirlenmesi, bakımın yoğunluğunun incelenebilmesinde önemli bir unsurdur. Sahip olunan torunların kaçının bakım faaliyetinden yararlandığı, büyük ebeveynlerin iş yükünde belirleyici olmaktadır. Bir çocuğun bakımını üstlenmek nispeten daha az sorumluluk taşırken, aynı anda veya ardı ardına birkaç torunun bakım sorumluluğunu üstlenmek, büyük ebeveynlerin ev içinde üstlendikleri rolleri artırabilmektedir. Bu gerçekten hareketle katılımcı büyük ebeveynlerin sahip oldukları ve bakım sağladıkları torun sayısının belirlenmesi gerekli görülmüştür. Araştırmanın verileri doğrultusunda, görüşülen büyük ebeveynlerin ortalama olarak 3 torunlarının bulunduğu ve bakım sağlanan torun sayısının 1-2 aralığında olduğu anlaşılmıştır. Katılımcı çiftler, eş zamanlı olarak en az 1 en çok 4 toruna bakım sağlamaktadır. Söz konusu bakımın yoğunluğu ailelerin ihtiyaçlarına ve torunun yaşına göre şekillendiğinden, torunların büyükanne-babalarının bakım desteğinden yararlanım süreleri değişkenlik göstermektedir. Bakım faaliyeti torunların hepsi için eşit şartlarda gerçekleşmese dahi, büyük ebeveynler sağladıkları uzun veya kısa süreli bakım desteğiyle orta kuşak için ihtiyaç halinde ulaşılabilir olmaktadırlar.

\subsubsection{Yaş özellikleri}

Büyük ebeveynliğin yaşamın hangi döneminde gerçekleştiği, hem torun bakım sorumluluğunu üstlenmeye ilişkin tutumları hem de bakım sağlayıcı olarak üstlenilen rolleri şekillendirmektedir. Büyük ebeveynliğe geçiş, potansiyel sağlık sorunlarının henüz gün yüzüne çıkmaya başlamadığı genç yaşlarda gerçekleştiğinde büyükanne-babalar torunlarına bakmak için daha fazla gönüllülük gösterebilmekte, bakım faaliyetinde aktif roller üstlenebilmektedir. Diğer taraftan büyük ebeveynlik rolüne giriş kötü sağlık koşulları ve düşük enerji riski taşıyan geç yaşlarda gerçekleştiğinde, büyük ebeveynler bakım 
sorumluluğunu üstlenmek istemeyebilir ya da bakım desteği için güçleri yetmeyebilir (Burgess, 2015: 72; Dunifon ve Bajracharya, 2012: 1171). Bu gerçek, büyük ebeveyn çiftlerinin yaşlarının sorgulanmasını gerektirmiştir. Katılımcı büyükannelerin yaş ortalaması 58.95 iken; büyükbabaların yaş ortalaması ise 63.8 'dir. Büyükbaba ve büyükannelerin aralarında bulunan yaş farkı, erkeklerin kadınlara kıyasla ilk evlenme yaşlarının daha yüksek olduğu yönündeki genel eğilime paralellik göstermektedir (TÜIK, Evlenme İstatistikleri, 2017). Torunlarına bakım sağlayan en genç büyükanne 49 yaşındayken, yaşça en büyük büyükanne 70 yaşındadır. Katılımcı büyükannelerin büyük çoğunluğunun (14 büyükanne) 5665 yaş aralığında yer aldığı, diğer yoğunlaşmanın 51-55 yaş aralığında (4 büyükanne) olduğu görülmüştür. Büyükbabalar arasında da büyükannelerle paralel biçimde 61-65 yaş aralığında yoğunlaşma ( 9 büyükbaba) görülmektedir. Ancak bir diğer yoğunluk (4 büyükbaba) büyükannelerin aksine, daha geç yaşı temsil eden 66-70 aralığında olmuştur. Bakım faaliyetine dahil olan en genç büyükbaba 53 yaşında, yaşça en büyük büyükbaba 73 yaşındadır.

Araştırmada büyük ebeveynlerin yaşlarının yanı sıra torunların yaşları da sorgulanmıştır. Torunun yaşı biryandan başlı başına çocuğun temel gereksinimlerinde belirleyici bir unsurken, diğer yandan çocuğun kreş ya da okula gönderilebilecek yaşta olup olmadığı, sağlanan bakım desteğini çeşitlendirmektedir. Bu sebeple torunların da yaşlarına ilişkin bir değerlendirme yapılmıştır. Bakım desteği verilen toplam 37 torundan büyük çoğunluğunun (23 torun) temel gereksinimlerinin karşılanmasında birine bağımlı olunan ve bu nedenle de yoğun bir bakım sorumluluğuyla ilişkilendirilen 0-6 yaş aralığında oldukları anlaşılmıştır. Yaşları 7 ile 10 arasında değişiklik gösteren torunların sayısı 12'dir. Bakım sağlanan torunlardan en küçüğü 3.06 yaşındayken en büyüğü ise 13 yaşındadır.

\subsection{3. Öğrenim durumu}

Eğitim düzeyi, büyük ebeveynlerin bakım faaliyetiyle bağlantılı olarak aile içinde üstlendikleri rollere etki etmektedir. Temel gereksinimlerin karşılanmasının ötesinde torunları hayata hazırlama sürecinde büyük ebeveynlerin üstlendikleri görevlerin neler olduğunun anlaşılabilmesi için eğitim durumlarının değerlendirilmesine ihtiyaç duyulmuştur.

Araştırmaya katılan bakıcı büyükannelerin öğrenim durumları incelendiğinde, ilkokul seviyesinde eğitimin katılımcı grup içerisinde yaygın olduğu (11 büyükanne) görülmektedir. Örneklemi oluşturan büyükannelerden 4'ü lise mezunuyken, 1 büyükannenin ilkokul 
eğitimini yarım bıraktığı tespit edilmiştir. Ortaokul mezunu büyükannelerle, lisans eğitimlerini tamamlamış büyükannelerin dağılımı ise eşittir (2'şer büyükanne).

Araştırmanın katılımcı büyükbabaların eğitim durumlarına ilişkin bulguları, Türkiye'de erkeklerin kadınlardan daha yüksek eğitime sahip olduğunu ortaya koyan eğitim istatistiklerinin verileriyle paralellik göstermektedir (TÜİK, Eğitim İstatistikleri, 2017). Bununla birlikte, büyükbabalar arasında da ilkokul düzeyinde eğitim yaygındır (8 büyükbaba). İlkokul düzeyindeki yoğunluğu, üniversite mezunları (5 büyükbaba) takip etmektedir. Ortaokul (3 büyükbaba) ve lise (4 büyükbaba) eğitimini tamamlayan büyükbabaların sayısı birbirine yakındır. Görüşmeler neticesinde ayrıca büyükanne-baba çiftlerinin büyük çoğunluğunun (14 çift) eğitim durumlarının birbirleriyle dengeli olduğu anlaşılmıştır.

Araştırmada elde edilen en çarpıcı sonuçlardan biri, farklı eğitim düzeylerine sahip büyükanne-baba çiftlerinin aile içinde torunlarına ilişkin üstlendikleri rollerin çarpıcı bir biçimde değişkenlik göstermiş olmasıdır. Bu bakımdan sonuçların büyük ebeveynlerin eğitim düzeylerine göre gruplandırılarak verilmesi uygun görülmüştür. $\mathrm{Bu}$ bağlamda ilkokul ve ortaokul mezunu büyük ebeveynler düşük eğitim seviyesine sahip grubu, lise ve üniversite mezunu büyük ebeveynler yüksek eğitim seviyesine sahip grubu temsil etmektedir.

\subsection{Bakım Kararı}

Araştırmanın en önemli verilerinden birisi, kadınların giderek artan oranda istihdamda yer almalarının her iki eğitim grubundaki büyük ebeveynlerin düzenli veya düzensiz olarak torunlarının bakımında görev almalarının ardında yatan temel dinamik olduğudur. Küçük çocuk sahibi babaların yanı sıra annelerin de işgücüne katılımları, büyük ebeveynlerin hemen hepsinin (16 büyük ebeveyn) birlikte ikamet etmedikleri torunlarına çocuk bakım hizmeti sağlamalarıyla sonuçlanmaktadır.

“...anne çalıştığı için mecburum, anne bir de işçi de değil bırakayım dese okumuş kadın, okuduğu için mesleğini yapmak zorunda..." (G6, büyükanne, ilkokul mezunu)

“...kızım çalışıyor diye bakıyorum torunlara. Vallahi hayattaki tüm amacımız kızımızın çalışabilmesi, kendi ayağının üzerinde dursun çalışsın şey yapsın yani. Biz çocukla ilgilenmezsek belki işe gidemeyecek, işini devam ettiremeyecek, onun için biz de fedakârlık yapıyoruz, 2 tane çocukla zor yani ama ne yapacaksın çocuklar için yapıyoruz...” (G20, büyükbaba, üniversite mezunu) 
Çift istihdam nedeniyle bakım sağlayan büyükanne-babaların, ebeveynlerin mesai saatleriyle paralel olarak yoğun bir bakım faaliyeti sürdürdükleri anlaşılmıştır. Çalışan ebeveynleri desteklemek amacıyla torunlarına bakım sağlayan 16 büyük ebeveyn çiftinin bakım sağladıkları toplam torun sayısı 27'dir. 3 yaşın altında olup herhangi bir kurum hizmetinden yararlanmayan ve orta kuşağın çalışma saatleriyle denk olarak haftanın 5 günü ortalama 10 saat büyük ebeveynlerinin bakımında olan torun sayıs1 10'dur. Bakım faaliyetinden yararlanan diğer torunların hepsi 13 yaş ve altında olup, kreş ya da okula gitmektedirler. Torunlarının kreş ya da okul yaşında olmaları, büyük ebeveynlerin torunları için (10 torun) yaz ve yarıyıl tatillerinde, torunlarının hastalığı gibi durumlarda ve ihtiyaç halinde bakım sağlamalarıyla sonuçlanmaktadır. Bununla birlikte, ortak hane düzenlemesi ya da okul saatlerinin ebeveynlerin mesai saatlerinden önce bitmesi gibi durumlar, okul-kreş tamamlayıcısı bazı büyük ebeveynlerin torunları için (7 torun) günlük olarak düzenli ve yoğun bir bakım faaliyeti sergilemesini gerektirmiştir. Ayrıca kreş ve okul tamamlayıcısı olan büyük ebeveynlerin bakım faaliyetini kreş ya da okul öncesinde, ebeveynlerin mesai saatleriyle paralel biçimde düzenli olarak sürdürdükleri anlaşılmıştır.

Çift istihdamın yanı sıra, çalışmayan kızlarının bakım ve destek ihtiyacı (5 büyük ebeveyn), babaların yoğun iş temposu nedeniyle evde pek bulunamaması (2 büyük ebeveyn) ve çocuklarının boşanma deneyimine sahip olmaları (1 büyük ebeveyn çifti), büyük ebeveynlerin düzenli bakım sağlamalarının temel sebepleridir.

“...12 yaşında olana hep ben bakıyorum, benim yanımda kalıyor, anne baba ayrı ona ben bakıyorum, onunla birlikte yaşıyoruz, benimle yaşıyor. Baba evlendi başka çocuğu oldu, anne gitti, çocuk iki tarafta da kalmak istemiyorum dedi. ...2.06 yaşında olanın da anne babası çalışıyor o yüzden ben bakıyorum ona da...” (G9, büyükanne, ilkokul mezunu)

“...anne evde ama vicdanen de rahatsız olduğum için haftada 3 gün falan gidiyorum, annenin evinde anneye yardımcı oluyorum sabahtan akşama kadar...” (G10, büyükanne, lise mezunu)

Bakım kararının ardındaki dinamiğe ilişkin çalışmanın saha kısmından edinilen veriler, çift gelirli ailelerin yükselmesi, orta kuşak babalardaki iş gücü oluşturma amaçlı şehirlerarası hareketlilik ve artan boşanmaların dahil olduğu ekonomik ve sosyal değişiklikler nedeniyle büyük ebeveynlerin tam zamanlı bakım sorumluluğunu üstlenebildiklerini ya da çalışan ebeveynleri desteklemek için kapsamlı bir çocuk bakım hizmeti sunduklarını ortaya 
koyan çalışmalarla (Villar vd., 2010; Mehta ve Thang, 2012; Bowers ve Myers, 1999; Herlofson ve Hagestad, 2012; Timonen ve Arber, 2012) paralellik göstermektedir.

\subsection{Zorunluluktan Bağımsız Tam Bir “Gönüllülük” Mümkün mü?}

Büyük ebeveynlerin torunları için bakım sağlama nedenleri düşük ve yüksek eğitim seviyesine sahip gruplarda benzerlik göstermekle birlikte, bakım ihtiyacına cevap vermeye yönelik tutum, gruplar arasında farklılaşır. $\mathrm{Bu}$ farklılığın temelinde, aile birliğine, aile yapılanmasına ilişkin görüşlerin değişiklik gösterebilmesi yatmaktadır.

“...başka torun olsa tabii canım ona da bakarız, sağ olduğumuz müddetçe ona da bakarız. Ben bekâr oğullarıma şimdi diyorum ki oğlum evlenin bak belki eşleriniz çalışmış olur, çocuklara bakılacak olur iyi kötü elimizden geldiğince bakarız...”(G15, büyükanne, ilkokul mezunu)

“...gelin üçüncü çocuğu hiç düşünmüyordu, kız hiç düşünmüyordu, ben dedim ki ben iki tane yaptım çok pişmanım şimdi, siz üçüncüyü de yapın ben maddi manevi sizin yanınızdayım, destekçinizim dedim. Sağ olsunlar onlar da benim sözümü tuttu, ben de onlara destek veriyorum..." (G18, büyükanne, ilkokul mezunu)

Düşük eğitim seviyesine sahip büyükannelere ait yukarıdaki anlatılar, bu gruptaki büyük ebeveynlerin evliliğin toplumun çıkarı için en iyisi olduğu inancına sahip olduklarını yansıtmaktadır. Büyükanne-babalar bekâr çocuklarının da aile kurmaları için baskıcı olabilmektedir. Evliliğin bir aile oluşturmak için atılan ilk adım olarak hizmet ettiği bu gruptaki büyük ebeveynler, çocuklarının çocuk sahibi olup aile değerlerini bir sonraki kuşaklara aktarmasını beklemektedirler. Ayrıca günümüz toplumlarında giderek yaygınlık kazanmakta olan "nitelikli tek çocuk” görünümünün de bu gruptaki büyük ebeveynlerce kabul görmediği, orta kuşaktan birden fazla çocuk beklendiği anlaşılmıştır. Aşağıdaki iki anlatıda da izlenebileceği gibi evlilik birliğini devam ettiren, birkaç çocuktan oluşan aileye ilişkin ideal görünüm, sadece kendi çocuklarından beklentilerini oluşturmamakta, toplumsal beklentilerini de yansitmaktadir.

“...şimdi anneler babalar bunu yapamıyor biliyor musun, susturalım durduralım diye aman ne istiyorsa yapalım, yanlış. İpin ucunu karıştırmamak gerekiyor, yani işin doğrusu bu. Sana da tavsiyem olsun, mutlaka çocuğun olacaktır..." (G9, büyükbaba, ortaokul mezunu) 
“...bu torunlara kıyılmıyor, yarın öbür gün evlendiğinizde sizler de göreceksiniz, siz de aynen öyle olacaksınız..." (G19, büyükanne, ilkokul mezunu)

“...oğlumun çocuğu yok, biz serbest bıraktık çocuk yapmaları konusunda, onlar da şimdi herhalde düşünüyorlar, biz hiçbir şey söylemeyiz asla, kendileri ne zaman isterlerse o zaman. ...bizim kızımız da geç evlendi ama hiç sorun değil, mutlu olsunlar. ...ben asla evlensin diye ima bile etmek istemedim çünkü o sorumluluk, benim baskımla evlenip de mutlu olmazsa ben kendimi huzursuz hissederim..." (G14, büyükanne, üniversite mezunu)

Yüksek eğitim seviyesine sahip büyük ebeveynlere gelindiğinde, onlar için de diğer gruptaki büyükanne-babalar için olduğu gibi çocuklarının mutlu olması esas öncelikleridir. Ancak bu grupta yer alan büyükannelerden birine ait yukarıdaki son anlatının da örneklediği gibi, bu gruptaki büyük ebeveynler, çocuklarının evlenip aile kurup çok çocuk sahibi olmalarını mutluluğun tek aracı olarak değerlendirmemekte, bekâr yaşam, çocuksuz aile gibi yeni aile görünümlerine karşı daha açık fikirli yaklaşmaktadırlar. Diğer yandan, düşük eğitim seviyesine sahip gruptaki büyük ebeveynler evlilik ve aile hayatına kutsal bir nitelik atfetmekte, çocuklarını evlenmeleri için zaman zaman baskılayabilmektedirler. Evliliğe ilişkin tutuma ek olarak orta kuşağın muhakkak çocuk sahibi olacağına dair kesin inanç, bu gruplarda geleneksel aile yapılanmasına ait değerlerin korunduğuna da işaret etmektedir. İdeal aile hayatına dair farklı bakış açıları, eğitim seviyeleri değişkenlik gösteren büyük ebeveynlerin torunlarının bakım faaliyetine yaklaşımlarına da yön vermektedir.

“...anne hamile olduğunu söyledi, ilk tepkim; Ne gerek vardı. Numaradan sevinmiş gözüktüm. ...o resmi bana getirdikleri zaman yani of yaptım, yani hiç istemedim Allah'ın gücüne gitmesin ama hiç istemedim de işte ne yapacaksın, mecburen. Ne yapsın yani mecbur k1z...”(G8, büyükanne, lise mezunu)

“...bu bir mecburiyet, keyfi falan değil kesinlikle çaresizlik. Damat çalışıyor senede bir ay izin var o da annesi ile ilgileniyor, kızım da öyle senede bir ay izni var. Çaresizlikten bakıyoruz yani başka bir şey yok. ...çocuklarıma yardım ediyorum o da güzel bir his ama yani mecburiyet de var işin içinde...” (G8, büyükbaba, üniversite mezunu)

“...bize sormalarına gerek yok, zaten biliyorlardı bakacağımı. Şimdi bir tane daha olsa yine bakacağım, ömrüm yettikçe...” (G9, büyükanne, ilkokul mezunu) 
“...bizim için toruna bakmak sıradan yemek yemek gibi bir şey, o kadar doğal. Nasıl normal acıkınca yemek yeme ihtiyacı hissediyorsun, toruna bakmak o kadar doğal yani..." (G9, büyükbaba, ortaokul mezunu)

Hem düşük hem yüksek eğitim seviyesine sahip büyük ebeveynler, çocuklarının yardım ihtiyacına cevap vermekte ve torun bakımı konusunda büyük sorumluluklar üstlenmektedirler. Bununla birlikte yüksek eğitim seviyesine sahip büyük ebeveynler torunlarına bakmanın gönüllülük esasına dayandığını belirtirken, aynı zamanda başka seçeneklerinin olmadığını da vurgulayarak bakımın mecburi bir seçim olduğuna dikkat çekmişlerdir. Çalışan kızlarını destekleyebilecekleri başka bir yöntem bulamamış olmaları ve kendilerinden başka bakacak kimsenin bulunmaması, bakım sorumluluğunu zorunlu katılım gerektiren bir faaliyete dönüştürebilmiştir. Ancak diğer başlıklar altında daha detaylı incelendiği gibi, bu büyük ebeveynlerin eş zamanlı olarak birden fazla toruna bakmaları, sosyal destek ağlarından bakım sürecinde yararlanamamaları gibi nedenlerin de bakıma ilişkin "zorunluluk" hissine sahip olmalarında etkili olduğu ifade edilebilir. Diğer yandan büyükanne-baba çiftlerinin yukarıdaki çapraz anlatılarından da yansıdığı gibi, ilkokul ve ortaokul düzeyinde eğitim seviyesine sahip büyük ebeveynler için torun bakımı, ebeveynliğin doğal bir uzantısıdır. Başka bir söylemle söz konusu büyük ebeveynler evlada ilişkin sorumluluklarının torun bakım faaliyetini de içerdiğini düşünme eğilimindedirler. Bakım faaliyetini üstlenmeye ilişkin bu yaklaşım, söz konusu büyük ebeveynlerin orta kuşak ile çok yakın hatta aynı apartmanda komşu olarak oturmaları ile sonuçlanmaktadır.

“...öbür eve oturtalım çocukları dedim, eşim dedi gelin çalışıyor yarın çocuğa kim bakacak, biz oraya gidip gelesiye kadar onlar buraya otursunlar. Onlar da sağ olsun istediler. Dede de bakmak istedi tabii canım, bizim göresiniz geldiğinde ta Konyaaltı'na mı gideceğiz dedi...” (G18, büyükanne, ilkokul mezunu)

“...çok yakınız birbirimize, alt üst oturuyoruz. Biz üç çocukla da yakınız, kendi apartmanımız bizim, aynı yerde oturuyoruz, biri altımda biri yan tarafımda oturuyor. İşleri olduğu zaman koyuyorlar, şey olunca...” (G19, büyükbaba, ilkokul mezunu)

İlkokul ve ortaokul mezunu büyük ebeveynlerin orta kuşakla aynı ev içinde oturmasalar dahi aynı avlu ya da aynı apartman içinde ya da çok yakın komşu olarak konumlandıkları görülmüştür. İlk anlatıda da yansıdığı gibi orta kuşakla mekânsal yakınlık, gelecekte doğacak torun bakım ihtiyacına yönelik ön hazırlık olarak ortaya çıkmaktadır. Diğer yandan yüksek eğitim seviyesine sahip grup için de yakın hane düzenlemesi söz konusudur. 
Hatta büyükbabalardan bazıları (4 büyükbaba) torunlarının bakım ihtiyacının orta kuşak ile aynı evde yaşamalarını gerektirdiğini belirtmişlerdir. Ortak hane düzenlemesinde sırf torun bakım ihtiyacına cevap verebilmek için yaşanılan şehrin değiştirilmesi de etkili olmuştur (1 büyük ebeveyn çifti). Bu grupta orta kuşakla yakın konumlanmanın geleceğe yapılan bir yatırımdan ziyade, bakım ihtiyacına cevaben ortaya çıkan bir gereklilik olduğu ve çoğu durumda geçici bir nitelik taşıdığı anlaşılmıştır.

\subsection{Gayrı Resmi Bakım Desteğine İlişkin Algı}

Katılımcı büyük ebeveynler torunları için çoğunlukla kapsamlı ve düzenli bir bakım programı üstlenmektedirler. Hâlihazırda kreş ya da okul tamamlayıcısı olarak bakım sağladığını belirten büyük ebeveynlerin dahi bu uygulamaya düzenli bakım faaliyetini takiben geçiş yaptıkları anlaşılmıştır. Üstelik yardımcı bakım yaz tatili, yarıyıl tatilleri gibi süreçlerde yeniden düzenli bakım niteliği kazanmaktadır. Dolayısıyla çoğu durumda bakım faaliyetinin yoğun bir biçimde devam ettiği ifade edilebilir. Uzun ve yükssek tempolu mesaiyi gerektiren bu sorumluluğun bir yardımcı ile paylaşılmasına yönelik tutumları sorgulandığında, eğitim durumunun yine gruplar arasında farklılıklara yol açtığı görülmüştür.

“...torun bakmak için en uygun kişi yine ben, anneanne ve babaannenin baktığını bakıcı bakabilir mi sanmıyorum, güvenemiyorsun ki, hele bu devirde, şu zamanda hiç güveniyorum...” (G2, büyükanne, ilkokul mezunu)

“...anne baba baktıkları için çocuklara gözü arkada değil. Ama bir bakıcı tutsa çocukları bıraksa işinde de randımanlı olamaz, aklı fikri sürekli evde olacak. Ne yaptı, yedirdi mi, aç mı bıraktı, uyuttu mu? Kazandığını da ona verecek...” (G20, büyükanne, ortaokul mezunu)

“...kı ne yapacak, bakıcı mı tutacak ben boşken. Bakıcı da tutsa benim başında durmam lazım..." (G8, büyükanne, lise mezunu)

“...biz eğer bakamayacak durumda olursak bakıcı parasını üstleniriz...” (G14, büyükanne, üniversite mezunu)

Her iki eğitim grubundaki büyük ebeveynler, orta kuşağın gayri resmi bakım desteğinden yararlanmalarına karşı çıkmış ve bakıcı karşıtı bir tutum sergilemişlerdir. Çocukların yabancıya emanet edilmesinden duyulan kaygı ve güvensizlik hissi, anlatılarda da yansıdığı gibi büyük ebeveynlerin bakım sorumluluğunu bakıcılara bırakmalarını ya da 
onlardan bakım sırasında destek almalarını engellemiştir. Büyük ebeveynler ayrıca gayri resmi bakım desteğini, ailenin maddi kaynaklarının boşa harcanması olarak da değerlendirmektedirler. Ancak yüksek eğitim seviyesine sahip gruptaki büyük ebeveynlerin çocuğun tüm sorumluluğunu tek başına üstlenmekten ziyade kendi gözetimlerinde olan ve evde "iş yüklerini azaltabilecek bir yardımcı" niteliği sergileyen bir bakıcı modelini onayladıkları anlaşılmıştır. Bu büyük ebeveynlerin zaman zaman çok bunaldıkları ve tüm gün mesai gerektiren bir bakım düzenlemesi dışında torun bakımına dahil olmayı tercih ettiklerine dair anlatıları da kendilerine nefes aldırabilecek bir kaynağa daha sıcak baktıklarını ortaya koymaktadır. Ancak büyük ebeveynlerin bu yaklaşımında eş zamanlı olarak birden fazla ve bir tanesi 3 yaşından küçük çocukların bakımını üstlenmiş olmalarının ve annelerin evde bulunmamasının esas etken olduğu belirtilmelidir. Üstelik bakıcı desteğine daha 1lımlı yaklaşmalarına rağmen yine de torunun bir başkasına emanet edilmesi fikrinden rahatsızlık duydukları da açıkça anlaşılmıştır. Bakıcıya ilişkin maddi kaynakların israfı değerlendirmesi, düşük eğitim seviyesine sahip büyük ebeveynler arasında da oldukça yaygın olmakla birlikte bu algı, bakıcı karşıtı tutumun temel nedenini oluşturmamaktadır. Söz konusu grupta büyük ebeveynler, "kendi canlarından olanı" para karşılığı "el” diye tanımladıkları birine emanet etmenin aile değerleriyle çatıştığını düşünmektedirler. Bunun yanı sıra, kendileri gibi geleneksel aile değerlerine sahip olan ve kendi torunlarının bakım faaliyetine aktif katılım gösteren sosyal çevrelerinin torunlarını bakıcıya bırakmaları halinde kendilerini ayıplayacağına dair farkındalıkları, gayrı resmi bakıcı karşıtı tavırlarında büyük etki sahibidir. Ayrıca, bu gruptaki çoğu katılımcıda görüldügü üzere, oldukça yakın oturdukları çalışmayan gelinleri/kızlarının çocuklarına anlık ihtiyaca cevaben bakım sağlıyor olmaları, söz konusu bakım desteğini gereksiz kılabilmektedir.

\section{5. Çocuk Bakım Faaliyetinin Kapsamı}

\subsubsection{Temel gereksinimlerin karşıllanması}

Bakım faaliyetinin kapsamı söz konusu olduğunda, eğitimde olduğu gibi, cinsiyet bağlamında da büyük farklılıklar olduğu belirtilebilir. Hem düşük hem de yüksek eğitim seviyesine sahip gruplarda çocuğun temel ihtiyaçlarını gidermeye yönelik faaliyetler, büyükannelerin çocuğa ilişkin öncelikli sorumluluklarını oluşturmaktadır. Özellikle torunu 3 yaşın altında olan büyükanneler torunlarının yedirilip içirilmesi, yıkanması, gün içinde sık sık tekrarlanan bezlerinin değiştirilmesi, uyutulması, giydirilmesi gibi temel çocuk bakım pratikleriyle bizzat ilgilenmektedirler. Büyükbabaların torunlarının temel gereksinimlerini 
karşılamaya yönelik tutumlarına gelindiğinde, eğitim durumunun büyükbabalarca sağlanan temel bakım faaliyetini oldukça çeşitlendirdiği ifade edilebilir.

“...kııım bizim bir şeyimiz yok, biz sabah gidiyoruz akşam geliyoruz. Geldiğimizde biraz seviyoruz, kafamız dolu olduğu zaman hemen git evine diyoruz. ...uzaktayken özlüyorum gelir gelmez soruyorum nerede bunlar diye ama sonra çok kafamız kaldırmıyor..." (G15, büyükbaba, ilkokul mezunu)

“...zaten toruna anneannesi bakıyor, halası bakıyor, teyzesi bakıyor, biz seviyoruz bolca. Bazen bakkala parka götürüyorum, nadir yani...” (G1, büyükbaba, ilkokul mezunu)

“...amcan yardımcı oluyor bana, ben mesela bazen rahatsız oluyorum o zaman yatıyorum, o ilgileniyor torunlarla. Parka götürüyor, markete falan götürüyor. ... ben bir hafta on günlüğüne şehir dışına gideceğim mesela şimdi, dede ile küçük kız toruna bakacaklar...” (G13, büyükanne, üniversite mezunu)

“...yemeğini de yediririm, eğlendiririm de, gezdiririm de. Ben evde olduğum zamanlar anneannesinden fazla ilgilenirim. Oynarız, çocuk da beni tercih ediyor. Çocuklarıma bakacak zamanım olmadı şimdi onların acısını çıkarıyorum, kendi çocuklarımız yerine de onların çocuklarını seviyoruz şimdi...” (G16, büyükbaba, lise mezunu)

“...çocuk bakımı, altını temizle üstünü temizle onu ben anlayamıyorum, zamanında anne çocuk sağlığı derslerimizde gördüğümüz halde, ona yaklaşamıyorum, onu çok iyi kavrayamadığım için, bilemediğim için. Zor bir şey değil, öğrenilir yapılır iş başa düşse ama o yok, onun dışında her türlü desteği verebilecek durumdayım..." (G12, büyükbaba, üniversite mezunu)

Yukarıda her iki eğitim grubundan olan büyükanne ve babaların birbirlerini destekleyen anlatıları da torunların temel gereksinimlerinin büyükannelerce karşılandığını ortaya koymaktadır. Ancak yüksek eğitim seviyesine sahip grupta büyükbabaların torunlarının temel gereksinimlerinin karşılanması konusunda eşlerine daha fazla yardımcı olma eğiliminde oldukları anlaşılmıştır. Bu eğilimde etkili olan faktörlerin başında, emeklilik gelmektedir. Söz konusu büyükbabalar biryandan kendi çocuklarını yetiştirdikleri süreçte çalışmak zorunda oldukları için evlatlarının bakımı hususunda yeterli sorumluluğu gösteremediklerine inanırlar. Diğer yandan çalışma hayatından ayrılmış olmak, ev dışında geçirilen zorunlu süreyi azaltarak, bakım faaliyetine aktif katılım için zaman yaratmaktadır. Gerek çocukların bakımında sorumluluk alınması gerektiği yönünde kazanılan farkındalık, 
gerekse de bunu faaliyete geçirebilecek yeterli boş zamana sahip olmak, büyükbabalık rolünün kendi canlarından olan bir çocuğun büyütülüp yetiştirilmesinde katkı sahibi olabilme firsatı olarak değerlendirilmesinde etkili olmuştur. Bununla birlikte, üniversite mezunu bir büyükbabaya ait yukarıdaki son anlatıda yansıyan "iş başa düşse" ifadesi bile başlı başına, büyükbabaların temel bakım ihtiyacına ne oranda cevap verirlerse versinler, ancak büyükannelerin yardımcıları olarak konumlanabildiklerine işaret etmektedir.

“...eşimin işi daha ağır bana göre tabi ben o kadar değilim. ...yani tamam torunumuz, bir süre çok güzel ama ondan sonra, ikimiz de artık yaşlandık, mesai olarak da çok yoğun sabah altı buçukta gidiyor eşim işte akşam yediye kadar tam mesai 12 saat yani yeniden anne baba olmak gibi. ...fiziksel olarak belirli bir yorgunluk da oluyor, ondan dolayı biraz üzülüyorum hem eşime hem kendime..." (G8, büyükbaba, üniversite mezunu)

“...eşim çok şikâyet ediyor, ona da çok kızıyorum. Çocuklara da söylüyor, o bana kıyamıyor, o ille bir söyleniyor anneniz hiç kendine bakamıyor, anneniz şöyle. Diyorum ben memnunum öyle deme çocuklara. ...benim eşim bana çok düşkün bütün derdi o, ben yoruluyorum diye..." (G12, büyükanne, lise mezunu)

Eşlerinin iş yüklerini azaltmaya yardımcı olabilme arzusu, yüksek eğitimli büyükbabaların temel gereksinimlerin karşılanması hususunda daha özverili davranmalarının bir diğer nedenidir. Torun bakım faaliyeti büyükanneler için çocukların temel ihtiyaçlarının karşılanmasıyla sınırlı olmamaktadır. Çocuk bakımı çoğu durumda, özellikle çalışan annelere yardımcı olmak maksadıyla orta kuşağın yemek, temizlik, evin eksiklerinin karşılanması gibi işlerinin üstlenilmesini de kapsar. Büyükanneler için bu durum, artan ev içi görevler anlamına gelmektedir. Yaşları artarken sorumlulukları azalmak yerine daha da fazlalaşan eşlerinin ev içinde üstlendikleri çoklu rolleri paylaşmaya gönüllü olan büyükbabalar, temel ihtiyaçların karşılanması sürecinde eşlerinin destekçileri olmaya çalışmaktadır. Ancak temel bakım faaliyetine nispeten aktif katılım, her zaman büyükbabaların kendi seçimleri doğrultusunda gerçekleşmemektedir. Yüksek eğitimli grubu temsil eden büyükbabalardan (9 büyükbaba) bazılarının (5 büyükbaba) aynı anda birden fazla torunları için bakım sağlamaları da eşlerin torunların sorumluluklarını paylaşmasını gerektirmekte ve büyükbabaları temel bakım sürecine daha fazla dahil etmektedir.

$\mathrm{Bu}$ gruptaki büyükbabaların ayrıca eşleri ile birlikte daha fazla aktivite içinde yer alabilmek maksadıyla da bakım sorumluluğunu paylaşmakta daha gönüllü oldukları anlaşılmıştır. Hem büyükannelerin hem de büyükbabaların kişisel deneyimlerine ilişkin 
anlatılarından, büyükannelerin torunlarının bakım ihtiyacına cevap verebilmek için eşleriyle birlikte geçirdikleri zamana ister istemez sınırlama getirdikleri anlaşılmıştır. Hatta bazı büyükanneler torunlarının temel gereksinimlerini karşılayabilmek için, eşlerinin ihtiyaçlarını ikinci plana ittiklerini vurgulamışlardır.

“...bizim eşimle birbirimize çok ihtiyacımız var. Eşim bir de benimle gezmeyi, benimle gitmeyi çok seviyor, birlikte olmayı çok seviyor. O, o kadar yalnız ki şu anda, yani bir başkası olsa belki çok rest çekebilir ama o da ne yapsın..." (G8, büyükanne, lise mezunu)

“...torunlar olmadan beraber sabah çıkıyorduk akşama kadar beraberdik ama şimdi 6 senedir çocuk doğdu doğalı koptuk. ...ben sorumluluğunun az olmasını çok isterdim yani şöyle bizim belirli yaştan sonra artık sağlıklı geçirebileceğimiz zaman daralıyor onu değerlendirebilmeyi istiyorum, biraz daha eşimle beraber sahile gideyim, dolaşayım, yurtdışına gideyim falan ama öyle bir şey olmuyor..." (G8, büyükbaba, üniversite mezunu)

Torun bakım sorumluluğu öncesinde çift olarak sosyal hayata daha aktif katılım gösteren büyük ebeveynlerin beraber yer aldıkları gezi, tiyatro, sinema, spor, günlük yürüyüşler gibi aktivitelere sınırlama getirmek zorunda kaldıkları anlaşılmıştır. Büyükanneler, eşleri ile aktivitelerinin yerini toruna ilişkin rolleri ile doldurmaktadırlar. Diğer yandan büyükbabalar torunun uyuduğu veya büyükannenin kendilerine ihtiyaçlarının olmadığ anlarda evden ayrılmaya hassasiyet göstermekle birlikte, eşleriyle paylaşmayı tercih ettikleri bu etkinlikleri kendi başlarına sürdürmeye çalışmaktadırlar. Ancak hoş zaman geçirmeye yönelik bu faaliyetlerin bile, özellikle düzenli bakımın sürdürüldüğü durumlarda her gün ve tek başına sürdürülmesi büyükbabalar için sıkıntılı olabilmektedir. $\mathrm{Bu}$ durum da büyükbabaları bakım sorumluluğunu paylaşmaya, torunlardan ayrı olmasa bile, onların da yer aldığg aktiviteler organize etmeye yönlendirmektedir. Ancak sürecin bütününe bakıldığında eşlerine kıyasla bu büyükbabaların kendilerine zaman ayırmak için daha fazla şansa sahip oldukları anlaşılmıştır.

İlkokul ve ortaokul eğitimine sahip büyükbabalara gelindiğinde, bu grupta ev işlerinin düzenli bir şekilde yapılması, bakım faaliyetinin yerine getirilmesi ve sevgi gereksiniminin karşılanması gibi anlamlı rollerin kadınların sorumluluğunda olduğu görüşünün yaygın olduğu anlaşılmıştır.

“...bizim annemiz bakıma muhtaç, artık tuvalete bile gidemiyor, biz dört kardeşiz, ben bir erkek evlat olmama rağmen ben bakamam demiyorum, sırayla herkes sırasını biliyor 
gidiyor mesela. İcabında yarın ben gidip ben bakacağım anneme, mesela tuvaletini de yaptırırım, yemeğini de yapıyorum...” (G7, büyükbaba, ilkokul mezunu)

“...babaanne yeterinden fazla ilgileniyor, o bir de çok anaçtır, evlatlara böyle çok aşırı düşkün, hiç of demez yani sevecendir..." (G9, büyükbaba, ortaokul mezunu)

Kendi annesinin bakımını üstlenerek evladi sorumluluğunu yerine getirmekte olduğunu ifade eden bir büyükbabaya ait ilk anlatıda yansıyan "erkek evlat olmama rağmen" ifadesi ile bakımı üstlenen anneannenin zaten yeterince anaç olduğuna ilişkin ikinci anlatıdan yansıyan ifade, bakım işinin bu gruptaki büyükbabalarca kadının işi olarak değerlendirildiği görüşünü desteklemektedir. Ayrıca aşağıdaki anlatılarda da örneklendiği gibi, çocuğun doyurulması, giydirilmesi, temizlenmesi ve uyutulması gibi temel gereksinimlerinin kadınlarca karşılanması gerektiğine dair genel kanı, söz konusu gruptaki büyükanneler arasında da yaygındir.

“...dede kalır onlarla, uslular çocuklarım benim şey yapmazlar öyle, amcan bakar. Pazara giderim ben mesela, dedesi ile kalırlar. Ben altını üstünü aldıktan sonra, karınlarını doyurduktan sonra ne olacak...”(G17, büyükanne, ilkokul mezunu)

“...amcan da aynı bakar, yerine göre bezini de alıyor yani, zaten kızı da çok seviyor, yemeğini de yedirir, her şeyi hemen hemen yapar o da, tabii anneninki kadar olmuyorsa bile gene de oluyor..." (G16, büyükanne, ilkokul mezunu)

Büyükbabalar arasında yaygın olan "bakım faaliyetinin kadının işi olduğu” görüşünün büyükannelerden de destek bulması, bu gruptaki büyükbabaların çocuğun temel gereksinimlerinin karşılanmasında geri planda durmalarında etkili olmaktadır. Günlerinin büyük kısmında ev içi görevler ve temel çocuk bakım işleri ile meşgul olan büyükannelerin aksine büyükbabaların günlük aktivitelerinin daha çok ev dişı alanda yoğunlaştığ anlaşılmıştır. İbadet, büyükbabaların günlük rutinlerinin başında gelmekte, büyükbabalar özellikle öğle ve ikindi namazlarını kayınbirader, ağabey gibi yakın akrabaları ve arkadaşlarından oluşan sosyal çevreleriyle birlikte camide k1lmaya özen göstermektedirler. $\mathrm{Bu}$ gruptaki büyükbabaların büyük çoğunluğu ya aile işlerini devam ettiren ya da kendi işini kuran oğullarına destek olmak hem de evde sıkılmamak için, kayda değer bir süreyi oğullarının iş yerinde geçirmektedir. Ayrıca, bu büyükbabalardan bazıları sahip oldukları sera ya da bahçelerde de vakit geçirmeye çalışmaktadırlar. Gün içinde evde pek bulunmadığ 1 anlaşılan bu büyükbabaların eşleriyle birlikte yaptıkları günlük aktiviteler de oldukça 
sınırlıdır. Bu durum, gün içinde büyükannelerinin yanında olan torunlarla etkinliklerini de sınırlamaktadır. Büyükbabalar daha çok büyükannelerin ev işlerini yaptığı zaman dilimlerinde torunlarıyla vakit geçirmekte, bu süre zarfinda da tercihen torunlarını parka, yürüyüşe veya markete götürmektedirler. Bu ihtiyaç ortadan kalktığında da eşlerini çocukla bırakıp dışarı çıkabilmektedirler.

Düşük eğitim seviyesine sahip bu gruptaki büyükbabaların torun bakımına daha az katılım göstermelerinde, büyük ebeveyn çiftlerinin sosyal çevrelerinin yakın akraba ve komşulardan oluşması da etkilidir. Sosyal çevrenin yakın akrabalardan oluşması, benzer ailevi değerlerin sık iletişim kurulan gruplarda da tekrarlandığına ve torun bakmaya yönelik benzer tutumların varlığına işaret eder. Diğer bir söylemle, düşük eğitim seviyesine sahip bu gruptaki büyük ebeveynler, kendileri gibi torun bakım sorumluluğunu alan veya almaya hazır akrabalarıyla sıkı ilişkiler içerisindedirler. Bu iletişim ağları içerisinde büyükanneler günlerini komşu ziyaretleri, dini toplantı ve sohbetler ve kadın oturma günlerinde geçirmektedirler. Büyükannelerinin bakım sorumluluğunda oldukları zamanlarda torunlar da bu etkinliklerin birer parçasıdır. Diğer yandan, büyükbabaların büyükannelerin sosyal çevrelerini oluşturan bu kadınların eşleri ile birlikte daha çok ev dışı alanda vakit geçirdikleri ve büyükannelerinin yanında olan torunlarla birlikte etkinliklerinin sınırlı olduğu anlaşılmıştır.

Söz konusu büyükbabaların torunlarının bakımında daha pasif bir rol üstlenmelerinin bir diğer sebebi, torunun annesinin ev hanımı oluşudur. Bu grupta bulunan 11 büyükbabadan 4'ünün istihdamda yer almayan kızları ya da gelinleri için bakım desteği sağladıkları anlaşılmıştır. Üstelik söz konusu dedeler, orta kuşakla aynı apartman ya da yan yana apartmanlarda oturmaktadırlar. Annenin iş gücü oluşturmaması, çocuğun temel bakımının anne tarafından karşılanması anlamına gelirken, bakımın kadın işi olduğu algısı, annelerin ihtiyaç duyduğu bakım desteğinin her an ulaşılabilir mesafede olan ve çocuk yetiştirme tecrübesine sahip büyükannelerden alınmasıyla sonuçlanmaktadır.

\subsubsection{Boş zaman değerlendirme çalışmaları}

Eğitim düzeyleri hangi seviyede olursa olsun, torunların temel bakım faaliyetinin baş aktörlerinin büyükanneler olduğu anlaşılmaktadır. Ev içinde ve dışında çocukla birlikte oyun oynama, çocuğa masal anlatma, çocuğu yaşıtlarının bulunduğu parklara götürme gibi çocuğun kişisel gelişimini destekleyici diğer etkinliklere işaret eden boş zaman değerlendirme çalışmalarında bulunmak, büyükannelerin torunlara ilişkin diğer rollerini oluşturmaktadır. 
Katılımcı büyükannelerin hepsi, torunlarının günlük temel ihtiyaçlarını karşılamanın ötesinde onlarla kişisel gelişimlerini destekleyecek aktiviteler düzenlemeye önem göstermektedirler.

“...mesela sabahleyin gidiyorum, o kalkıyor yüzünü falan yıkıyorum, dişini firçalıyor. Biraz uykusunu açtıktan sonra kızım ne yersin, anneanne şunu yap derse kalkıyorum onu yapıyorum ve birlikte kahvaltımızı yapıyoruz. Ondan sonra biraz sohbet ediyoruz, şarkı, türkü söyleyip şiir söyleriz, top oynuyoruz. Çok güzel masal anlatırım o da bana anlatır. Ondan sonra biraz oturuyoruz çizgi film izliyoruz 15 dakika falan. Ondan sonra geri kalkıyoruz birlikte evcilik falan oynuyoruz. Saat bire doğru uyuyor, o uyurken ben yemeğimi falan yapıyorum. Altını üstünü değiştir, duşunu aldır..." (G2, büyükanne, ilkokul mezunu)

Büyük ebeveynlerin torunlarıyla olan zamanlarını eğlenceli ve nitelikli bir biçimde değerlendirebilecekleri faaliyetlere katılımlarına işaret eden boş zaman değerlendirme çalışmaları, yukarıdaki anlatılardan da yansıdığı üzere büyükanneler için ancak torunların temel ihtiyaçları karşılandıktan sonra mümkün olabilmektedir. Torunlarının temel bakım gereksinimlerini karşılama sorumluluğunu üstlenen büyükanneler ayrıca yemek, bulaşık, temizlik, ütü gibi ev işlerinden oluşan günlük rutinlerini de yerine getirmektedirler.

“...orada kaldığımda çocuk bakımı dışında yemek falan ben yaparım, ben duramam yani. Ben evimde olsa bile gelin annem derim, akşama kadar yoruluyorlar, çalışma hayatını da bildiğim için gelin yemeğinizi yiyin gidin derim..." (G6, büyükanne, ilkokul mezunu)

“...torunlar çoğu zaman bende kalıyorlar, ikisi de bende kalıyor. Hep beraber kalıyorlar hatta anne baba da bende kalıyor, hep beraber. Benim işim çok yoğun oluyor, bir yemek yiyoruz kalkıyorlar gidiyorlar. Toparla, temizle, ben kıza söylüyorum kızım sen çalışmıyorsun esas çalışan benim diyorum, tekrar anne oldum...(G13, büyükanne, üniversite mezunu)

Hangi eğitim grubunda olurlarsa olsunlar çift istihdam nedeniyle torun bakımını üstlenen büyükannelerin hepsi çalışan kızlarının/gelinlerinin iş yüklerini azaltabilmek için onların ev işlerine de yardımcı olmakta ya da en azından eve geldiklerinde yiyebilecekleri akşam yemeklerini hazır bulundurmaktadırlar. Tüm bunlara ek olarak bazı katılımcılar (14 büyük ebeveyn) eş zamanlı olarak birden fazla torunun bakım sorumluluğunu üstlenmektedir. Tüm bu faktörler neticesinde, büyükanneler torunlarının boş zaman aktiviteleri için çoğunlukla büyükbabalardan destek almaktadırlar. 
“...ben getir götürcüyüm, benim fazla fonksiyonum yok. ...ben yaz olduğunda bizim yaylada elektrikli motor var torunları onla gezdiriyorum, markete gidiyoruz bir şeyler alıyoruz, nerde ağaç gölgesi var orda gazozumuzu içip, çubuğumuzu yiyip muhabbet ediyoruz. Burada da okula götürüp getiriyorum başka bir şey yaptığım yok..." (G6, büyükbaba, ilkokul mezunu)

“...toruna anneanne bakıyor, ben de onların yanlarına gidiyorum görüşüyoruz. Bir şey isterlerse gidiyorum götürüyorum. Ben onların ihtiyaçlarını karşılıyorum bir yerlere gideceklerse onları götürüyorum..." (G11, büyükbaba, ilkokul mezunu)

“...boş zamanlarımızda dışarı çıkıyoruz, yürüyüş yapıyoruz. Ya onu bisiklete bindiriyorum ya oyun merkezlerine, parka götürüyorum, vakit öyle geçiyor yani...” (G5, büyükbaba, lise mezunu)

“...esas olarak tabii eşim bakıyor bütün ağırlık onda, yani 100'e bölersek \% 20'si falan benim, \%80'i onun. Ben çocukları daha çok evde oyalıyorum, bazen güneşlendirmek için sokağa çıkarıyorum, uyutuyorum, sokakta dolaştırıyorum ya da sahilde uyutabilirsem uyutuyorum..." (G8, büyükbaba, üniversite mezunu)

Büyükbabalara ait anlatılarda da izlendiği üzere torunlarla bir şeyler okuma, spor aktivitelerine katılma, park ve oyun alanlarına gitme, televizyon izleme, oyun oynama, alışverişe gitme gibi büyükanneler için temel bakımı destekleyici etkinlikler, büyükbabaların toruna ilişkin öncelikli bakım faaliyetini oluşturmaktadır. Bu bağlamda büyükbabaların boş zaman değerlendirme çalışmaları kapsamında torunlarıyla gerçekleştirdikleri aktivitelere ilişkin saha verileri, büyükanne ve babaların torunlarıyla gerçekleştirdikleri faaliyetlere dair AARP (2002: 17-18) raporunun sonuçlarıyla paralellik göstermektedir.

\subsubsection{Aile değerlerinin torunlara öğretilmesi}

Katılımcı büyük ebeveynlerle yapılan derinlemesine görüşmeler neticesinde, ailenin kültürel değerlerinin torunlara aktarımı konusunda da büyük ebeveynlerin sorumluluk hissettikleri anlaşılmıştır. Torunlarının ailenin sahip olduğu kültürel mirasa dair bir bilinç kazanması, özellikle büyükbabaların hassasiyet gösterdiği bir konu olmuştur. Kültürel mirasın torunlara aktarımı konusunda özellikle ilkokul ve ortaokul mezunu büyükbabaların etkin bir rol oynadıkları anlaşılmıştır. Düşük eğitim seviyesine sahip bu gruptaki 11 büyükbabanın hemen hepsi (8 büyükbaba) Antalya'nın çeşitli köylerinden olduklarını, diğerleri de Antalya iline bağlı olmasa da köy yaşantısı deneyimine sahip olduklarını belirtmiştir. Üstelik bu 
büyükbabaların büyük çoğunluğu (7 büyükbaba) yaz aylarını Kumluca, Korkuteli, Karaöz gibi ilçelerde bulunan köylerinde geçirdiklerini vurgulamışlardır. Geçim kaynağı tarım olan bu büyükbabalardan bazıları, emekli olmadan önce gerçekleştirdikleri seracılık işini aktif olarak devam ettirmeseler de ortakçılar ya da oğulları aracılığıyla sürdürmektedirler. Bu bakımdan toprak, hayatlarında oldukça büyük bir öneme sahiptir. Hâlihazırda şehirlerde yaşamakta olan söz konusu büyük ebeveynler, topraktan tam anlamıyla kopmuş değillerdir ve köy hayatına ait kültürel değerleri de yerleştikleri şehirlerde sürdürmektedirler.

“...ben evin üstünde iki, üç tavuk besliyorum, köy hayatı gibi onunla uğraşıyorum, torunlara organik yumurta yetiştiriyorum, bıldırcın var yumurta veriyoruz. ...bak bahçede bir sürü meyve ağacı olsun, çoluğun çocuğun gelip de şu ağaç nedir diye bakan da olmayacak, bak bu nesil böyle ne olacak bilmem. ...şimdi bir elinde bir telefon onunla akşama kadar elleşiyor, ne olacak bu sonu? Vaktini değerlendirip de şöyle bu ağaç nasıl büyüyor, nasıl çapalanır, nasıl sulanıyor, nasıl belirleniyor, nasıl budanır yok, merak yok... Benim evim bahçe gibi evin tavanına akasyalar yetiştirdim, evin üstünde asmalar var, 1520 tane toprak dolu küvetler var hepsinde sebze yetiştiriyorum ama torunlar onu görmüyor, umumda böyle bir pasiflik var. ...şimdi çocuk evin içinde kapana kapana toprak görmüyor ya, ayağına basacak toprak yok. Biz köylerde yalınayak toprakta gezerdik, ayağımızın cereyanını alırdı, stresini alırdı. Şimdi stres nereden oluyor, kapalı çocuk nereye gidecek? Ayağı toprak görmüyor, sinirli... çocuk öyle öyle alışmış en kolay neyse, en hazır neyse, en basit neyse her şey elinde. Dünya elinde oynayacaklar ama bunu babam nasıl etmiş, nenem nasıl yapmış, annem nasıl yapmış, dedem nasıl yapmış yok...” (G18, büyükbaba, ilkokul mezunu)

“...bizim köy buraya 40 kilometre, hafta sonları oraya gidiyoruz çocuklar oraya geliyor, onlarla orada bayağı bir muhabbet yapıyoruz. Köy havası da onlara hoş geliyor. Bende biraz av hastalığı var ava gidiyorum, balığa gidiyorum köye gidip torunlarla balığa gidiyoruz..." (G19, büyükbaba, ilkokul mezunu)

Anlatılarda da görüldüğü üzere, "köylü” olan bu büyükbabalar köy yaşamına ait sahip oldukları değerleri torunlarının öğrenmesini, hatta torunlarının kazanmasını istemektedir. Bunun için şehir içinde köy hayatına ait pratikleri yaşatmaya çalışmakta, yani bir anlamda köy hayatını şehre taşımaktadırlar. Torunlarını da okulları imkân verdiği sürece köyde yetiştirmeye ve ailenin sahip olduğu o kültüre ait olanı torunlarına öğretmeye çalışmaktadırlar. Toprağı sevme, doğal yaşamda avlanma gibi etkinlikleri torunlarıyla paylaşmaktadırlar. 
Yüksek eğitim grubundaki büyük ebeveynlere gelindiğinde ise, aile değerlerini kuşaklara aktarma konusunda "köy kültürünü şehre taşımak" denli somut adımlar atmadıkları ifade edilebilir. Söz konusu büyük ebeveynlerin daha çok torunlarının ailevi doğrularla yetiştirilmesine katkı sağladıkları anlaşılmıştır. Kendi kuşaklarına kıyasla orta kuşağı ve de özellikle üçüncü kuşağı daha saygısız, çevreye ve topluma duyarsız olarak değerlendiren büyük ebeveynler, ailenin doğru değerlerini torunlara öğretmede yaptıkları rehberlik noktasında katkı sağlamaktadırlar.

“...bizim zamanımızda öğretmen okulda döverdi, gerekirse eve gelirdik bir de babamıza şikâyet ederdi babamızın yanında da döverdi. Şimdi bir tane öğretmen çocuğa bir şey dedi mi elinde bir telefon Facebook'tan hemen şikâyet ediyor, adliyenin kapısını tutuyor, öğretmen ekmeğinden oluyor. Lisede çocuğum var, utanıyorum yani öğretmenleri hakkında ettiği lafları duyunca. Çocuklar şimdi çete olmuş, öğretmene bıçak, silah çekme, yolunu kesme..."(G16, büyükbaba, lise mezunu)

Z kuşağına yönelik olumsuz alg1, büyük ebeveynlerin biryandan kendi yetiştirildikleri değerlere daha sıkı bağlanmasında ve torunlarının bu bilinçle yetiştirilmesinde etkili olmuştur. Diğer yandan söz konusu büyük ebeveynlerin modern hayatın gereklilikleri konusunda da daha yüksek bir farkındalığa sahip oldukları anlaşılmıştır. Bu farkındalıkları, alt başlıkta da tartışılacağı gibi, torunlarını modern hayata hazırlama konusundaki hassaslıklarına temel hazırlamıştır.

Torunların aile değerlerini içselleştirmesi konusunda her iki eğitim grubundaki büyük ebeveynlerin kendi doğru bildikleri yöntemler doğrultusunda adımlar attıkları anlaşılmıştır. Değerlerin aktarım yolu, düşük eğitim seviyesine sahip grupta torunların günlük yaşam pratiklerinden farklı yaşam düzenlemeleri biçiminde daha görünür bir nitelikteyken, yüksek eğitim seviyesine sahip büyük ebeveynler arasında hayata hazırlamak için yapılan rehberlik biçiminde karşılık bulmaktadır.

\subsubsection{Güvenilir bir danışman, iyi bir rehber}

Büyük ebeveynler, bakım faaliyeti kapsamında kendi bilgi, deneyim ve birikimlerini torunlarına aktaran, onlara örnek olup danışmanlık sağlayan kişiler olarak da konumlanmaktadırlar. Torunlarının pratik bilgi, becerilere olan ihtiyaçlarına cevap veren büyük ebeveynlerin aktarımları, eğitim durumları, meslekleri, sosyoekonomik durumları ve kişisel ilgi alanlarıyla yakından ilişkilidir. $\mathrm{Bu}$ becerilerin aktarılmasının torunlarının 
gelişimine dikkate değer bir katkı sağlayacağını düşünme eğiliminde olan büyük ebeveynlerin rehberlik rollerine oldukça önem gösterdikleri anlaşılmıştır. Torunları için iyi birer örnek oluşturmayı arzulayan büyük ebeveynlerin özellikle torunlarının ahlaki rehberliklerini üstlendikleri, torunlarına doğruyu, güzeli, dürüst olanı öğretmeye çalıştıkları anlaşılmıştır. Her iki gruptaki büyük ebeveynler için torunlarının iyi ve doğru değerlerle yetişmesi oldukça büyük bir öneme sahiptir. Ne var ki iyiye, doğruya ilişkin değerler gruplar arasında farklılık göstermektedir. Üstelik bu değerlere ulaşmak için izlenmesi gereken yollar da gruptan gruba değişmektedir.

İlkokul ve ortaokul eğitimine sahip büyük ebeveynler arasında kalbinde Allah sevgisi barındırmak, dini uygulamaları benimsemek "doğru” değerlere sahip olmanın öncelikli şartı olarak hizmet etmektedir. Torunlarının dini rehberliği ise daha çok büyükbabaların sorumluluğundadır.

“...dini değerler önde geliyor, onları öğretiyorum. Torunlarım Kur’an-1 öğrendiler maşallah..." (G7, büyükbaba, ilkokul mezunu)

“...torunların da hepsi aynı Kur’an-1 öğrendiler, gelinlerimin de benim gayretleri var tabii sadece benim gayretimle değil... Biz dört kardeşiz biz babamızı iki yaşımızda kaybettik, en küçükleri benim, bizim dördümüzün de sigarası dahi yok, kumarımız başka şeyimiz olmadığı gibi, şeyimiz bile olmadı cigaramız. O bakımdan çok şükür Allah'ımıza Cenabı Allah inşallah torunlarımıza da, çocuklarımıza da böyle bir amel versin..." (G19, büyükbaba, ilkokul mezunu)

“...bizdeydi sabah Kur’an kursuna götürdüm, gidip geri alıp geleceğim...” (G3, büyükbaba, ortaokul mezunu)

$\mathrm{Bu}$ gruptaki büyük ebeveynler için dini rehberlik rolünün salt torunlarıyla birebir ilişkilerinde ortaya çıkmadığı, aynı zamanda aile, arkadaş toplantıları sırasında da gerçekleşebildiği, özellikle büyükannelerin günlerini nasıl değerlendirdiklerine ilişkin anlatılarından anlaşılmıştır.

“...ben çok aktifim, gezerim. Cuma sohbeti, Kur’an toplantım, günlerim vardır. Sabah kalktık mı şimdi babaanne nereye gideceğiz diyor..." (G18, büyükanne, ilkokul mezunu)

“...güne giderim haftada bir, cuma günleri Yasin toplantımız olur, sağ olsun apartmanımızda var komşularımız, gelir beraber indirirler. Şimdi indiriyorum artık oğlan 
yürüyor çünkü artık, rahat merdivenden inebiliyor, kızı da kucaklayıveriyorum indiriyorum..." (G17, büyükanne, ilkokul mezunu)

İlkokul ve ortaokul eğitimini tamamlamış büyükanne ve babalar için dini rehberlik, torunlarına ilişkin üstlenmiş oldukları önemli rollerden biri olarak gözükmektedir. Büyükbabalar kendi ritüelleriyle örnek oluşturmak ya da bu ritüelleri birebir öğretmek yoluyla torunlarının manevi değerleri kazanmalarına yardımcı olurken; büyükanneler ise gündelik yaşamlarının birer parçası olan Cuma sohbetleri, Kur'an okuma günleri gibi etkinliklere torunları da dahil etmek yoluyla onların bu değerleri kazanmalarının aracıları olmaktadırlar.

Düşük eğitim seviyesi grubundaki büyük ebeveynler torunlarının “doğru, etik ve iyi” olan değerlere sahip olmaları için, Allah sevgisi ile birlikte ataya saygı bilinci kazanmaları gerektiğine inanma eğilimi göstermektedirler.

“...çocukların eğitimi de ailede çok önemli, bir el öpmeyi bilsinler, bunu öğretirsen unutması zor ama şimdikiler el öpme, ötekini yapma, berikini yapma, ondan sonra ne oldu çocuklar..." (G9, büyükbaba, ortaokul mezunu)

“...bak evlenenler, ayrılanlar görüyorsun, boşananlar, Allah’ın sevmediği bir şey bu, şimdi öyle bir zaman gelmiş, hep bu şımarıklık değil mi. Birbirleriyle geçinemiyorlar, en ufak lafi kaldırmıyorlar, en ufak zorlamaya sıkıntıya gelmiyorlar, en ufak bir incir çekirdeğini doldurmayacak bir şeyden hemen ayrılıyorlar, ne biçim iş bu. ... benim o kadar içim sızlıyor bu insanların bu kadar her şey hazır, huzur yok. Her şey var, itaat yok, saygı yok, sevgi yok. Ne adamlar var huzurevinde yatıyor, bu nesil hiç bakmayacak...” (G18, büyükbaba, ilkokul mezunu)

“...çocuklarım bize bakarlar ümidim var, babası da çok bakardı kayınpederime, yaşlıydı hastaydı, bizden gördüğünü yapar aynı şekilde bize diye düşünüyorum..." (G16, büyükanne, ilkokul mezunu)

Yukarıdaki anlatılarla da örneklendiği üzere evlatların büyükleri sevip sayması, onlara hürmet etmeleri, evladi sorumluluğun bir parçası olarak değerlendirilmektedir. Bu gruptaki büyük ebeveynlerin torunlarının büyüklere, yaşlılara, özellikle babalarına ve atalarına saygılı bir biçimde yetiştirilmeleri sorumluluğunu üstlendikleri anlaşılmıştır. Büyük ebeveynler kendi büyüklerini sayma, onların ihtiyaç duyduğu bakım desteğini sağlama yoluyla da torunlarına örnek oluşturmaktadırlar. Ayrıca büyükbabalara ait örnek anlatılar, atalara saygı olgusunun yalnızca anne-baba, eşin anne babası ve yaşça büyük akrabalara duyulan saygıdan ibaret 
olmadığını yansıtmaktadır. Bu gruptaki büyük ebeveynler arasında kadınların eşlerini de ataları olarak kabul edip saymaları gerektiği görüşünün yaygın olduğu ve bu bağlamda da geleneksel aile değerlerinin yansıtıldı̆̆ ifade edilebilir.

“...babama 10 yıl hizmet etme firsatı verdi bana Allah, ben bundan memnunum böyle bir firsat verdiği için Allah. Hastalığa da şükredilir mi, ediliyor bazen. Öbür pencereden bakarsan ebeveyn evlada ihtiyaç duymadan gitse daha iyi, ebeveyn açısından ama ben de hizmet firsatı yakaladım diye düşünüyorum, ben ayrı pencereden bakıyorum..." (G16, büyükbaba, lise mezunu)

“...ben şimdi babama baktığım için diyorum ara sıra olur ya ileride bana bir şey olursa yatalak falan olursam beni bakımevine götürün bırakın. Onlar da karşı çıkıyorlar sen dedeme baktın da biz sana mı bakmayacağız diyorlar...” (G13, büyükbaba, üniversite mezunu)

Diğer yandan yüksek eğitim seviyesine sahip büyük ebeveynler de gerek kendi büyüklerine bakım sağlayarak örnek olmak gerekse de büyüklere hürmeti, hizmeti yaşamlarını anlamlı kılan bir değer olarak sunmak yoluyla torunlarına atalara saygı bilincinin aşılanmasında sorumluluk almaktadırlar. Yüksek eğitim seviyesine sahip bu grupta saygı, daha çok büyüklere hürmet edilmesi, bakım ihtiyaçlarının karşılanması ve kadınların eşlerine itaatinden ziyade eşlerin birbirlerine, birbirlerinin ailelerine itibar etmeleri biçiminde karşıllk bulmuştur.

“...ben sadece çok iyi yetişsin istiyorum torunlar. Arkadaşları ile güzel geçinsin, kötü olmasın, kavga etmesin. Hep böyleydi yetiştirmem, arkadaşı bir şey yaptığı zaman boş ver yavrum bir dahaki sefere yapmaz, sen böyle davranma. Kızım diyor ki anne böyle yetiştirmeyeceksin, sen ne dersen o olur diyeceksin, seninle konuşmak istemedi mi konuşmasın sen de onunla konuşma. Bunlar bana çok çirkin geliyor, böyle yetiştirmek istemiyorum ama böyle yetiştirmezsen de çok ezilecek o çocuk. Bu nesil özgüvenli olsun diye çok saygısız bir toplum yetişiyor, çok kötü bir toplum geliyor şimdi...” (G8, büyükanne, lise mezunu)

Yüksek eğitim seviyesine sahip büyükannelerden birinin yukarıdaki anlatısında da üzerinde durduğu gibi, bu gruptaki büyükanne ve baba çiftleri ayrıca, torunlarının topluma ve toplum yaşantısına da saygılı olmaları hususunda hassaslık göstermekte, hatta bu konuda kimi zaman orta kuşakla da çelişebilmektedirler. 
Yüksek eğitim seviyesine sahip büyük ebeveynler için rehberlik rolü, belli bir dine bağlı olmakla ilgili olmamaktadır. Bu gruptaki büyük ebeveynler, torunlarına dürüst, kibar ve etik olanı öğretmenin yanı sıra, bilgi ve deneyimlerini onlarla paylaşmaya, onlara eğitim hayatlarında ve mesleki hayatlarında yararlanabilecekleri beceriler kazandırmaya önem vermektedirler.

“...torunlara yardımcı oluyorum, onlarla ilgileniyorum, sorular soruyorum, imtihan yapıyorum, not veriyorum. Vallahi küçük kız da yapabiliyor işlemleri, ben emek veriyorum o da karşılı̆̆ını gösteriyor...” (G20, büyükbaba, üniversite mezunu)

“...eğitim kökenli olduğumuz için torunuma da bu konuda rehberlik yapmak isterim. İnsanlara karşı davranışlarında çok şey yaparım hassas olurum, sorunlarını çözebilmesinde kendi sorununu kendisi çözmesi konusunda biraz şey yaparım...” (G14, büyükbaba, üniversite mezunu)

“...cumartesi günleri buradan çıkıyoruz dokuz buçukta jimnastiğe gidiyoruz, oradan çıkıyor baleye, resim kursuna, resimden çıkıyoruz kodlamaya götürüyorum bilgisayar kodlama şeyine. Şimdi onu da çok verimli bulmadım onu bıraktık başka bir yere götüreceğim şimdi sevmedim onu.” (G8, büyükanne, lise mezunu)

Söz konusu büyük ebeveynler, zaman, enerji kaynaklarını torunları için harcamaları, torunlarıyla bilgi ve becerilerini paylaşmalarının yanı sıra, ayrıca finansal olarak da torunlarının geleceklerine yatırım yapmaktadırlar. Gelecekte eğitim ve meslek hayatlarında başarı sağlayabilmeleri için torunlarını çeşitli kurslara göndermek ve bu kursların maliyetini karşılamak, büyük ebeveynlerin torunlarına yaptıkları yatırımlara işaret etmektedir.

\section{SONUÇ VE DEĞERLENDİRME}

Risk altındaki aileler olgusunu ve aileye alternatif yeni modelleri dünya çapında yaygınlaştıran sosyolojik ve demografik dönüşümler, 1980’lerden bu yana her geçen gün daha fazla büyük ebeveynin torunlarının bakım faaliyetine dahil olmalarına yol açmaktadır. Büyük ebeveynlerin sağladıkları bakımın yoğunluğu ise, ailelerin ihtiyacına cevaben şekillenmektedir. Büyük ebeveynler torunlarının bakım sorumluluklarını tek başlarına üstlenebildikleri gibi, torunları için uzun süreli ya da ihtiyaca cevaben anlık bakım sağlayabilmektedirler. Bir başka anlatımla, bakım ihtiyacını yaratan ailevi koşullar, bakımın niteliğini belirlemektedir. $\mathrm{Bu}$ çalışma dahilinde görüşülen büyük ebeveynlerin çoğunlukla, işgücü oluşturmaları nedeniyle çocuklarının bakım ihtiyaçlarına cevap veremeyen annelerin 
yerine bakım faaliyetini üstlendikleri anlaşılmıştır. Torun bakımını yaratan sık eş değiştirme, tek ebeveynlik, orta kuşakta yaşanan madde bağımlılığı, kronik fiziksel/ zihinsel hastalıklar, ölüm, tutukluluk hali, çocuk istismarı gibi diğer nedenlere örneklem içinde rastlanılmamıştır. Boşanma nedeniyle torunlarının tüm bakım sorumluluğunu üstlenme durumu yalnızca bir büyük ebeveyn çifti için geçerlidir. Bununla birlikte, görüşülen büyük ebeveyn çiftlerinden bazıları boşanma deneyimlerine sahip, bazıları evliliklerini çocuksuz sürdürmeye karar vermiş olan, bazıları da geç yaşta olup bekâr olan çocuklara sahip olduklarını belirtmişlerdir. Her ne kadar torun bakma sebeplerini oluşturmasa da bu durum, görüşülen büyük ebeveynlerin sahip oldukları çocukları aracılığıyla yeni aile görünümlerine katkı sağladıklarına işaret etmektedir.

Çocuklarının destek ihtiyacına cevap vererek torunlarının bakım sorumluluğunu üstlenme konusunda aynı gönüllülüğü gösteren büyükanne-babaların bakım faaliyetine katılımları ve bu süreçte oynadıkları roller farklılaşmaktadır. Torunların temel bakımlarını yerine getirme sorumluluğu büyük ölçüde büyükannelerdeyken; büyükbabaların bu sorumluluğa katılım düzeyleri ise eğitim durumlarına göre çeşitlenmektedir. İlkokul ve ortaokul mezunu büyükbabalar gün içinde torunlarıyla birlikte çok zaman geçirmedikleri gibi, torunlarının yedirilip içirilmesi gibi temel gereksinimlerini karşılamaya yönelik sorumlulukları paylaşmama eğilimi sergilerler. Ancak büyükanne ile torunun bir yere götürülmesi ya da torunun bez, mama gibi günlük ihtiyaçlarının karşılanması konusunda sorumluluk almaktadırlar. Ayrıca, büyükannelerin kısa süreli destek ihtiyacına cevaben torunlarını parka, bahçeye de götürebilmektedirler. Diğer yandan lise ve üniversite mezunu büyükbabaların torunun temel ihtiyaçlarının karşılanması konusunda daha duyarlı davrandıkları ifade edilebilir. Bu büyükbabalar gerek çocuk sahibi olmaya ilişkin duyguyu yaşamak, gerek eşlerinin iş yükünü paylaşmak, gerekse de eşleri ile kendilerine fursat yaratmak için çocuğun temel ihtiyaçlarının karşılanmasında daha etkin bir rol oynamaktadırlar. Bununla birlikte ister düşük ister yüksek eğitim seviyesine sahip olsunlar, torunların temel ihtiyaçlarının öncelikli olarak büyükanneleri tarafından karşılandığ anlaşılmıştır.

Torun bakımı dahilinde büyük ebeveynler ayrıca torunlarıyla birlikte nitelikli zaman geçirecekleri aktiviteler içinde bulunmaya da özen göstermektedirler. Bunun yanı sıra aile değerlerinin torunlara öğretilmesinde de büyük ebeveynler çeşitli roller üstlenmektedirler. Torunlarının nereden geldiklerini bilmeleri, ailenin değerlerine, gelenek göreneklerine ilişkin bir farkındalık kazanmalarında büyük ebeveynlerin katkıları oldukça fazladır. Büyük ebeveynlerin torun bakım faaliyeti, aynı zamanda torunlarını iyi, doğru ve ahlaklı olana 
yönlendirme, torunlarıyla bilgi, deneyim ve becerilerini paylaşarak onların geleceğine yatırım yapma fırsatı olarak da işlev görmektedir. Araştırmanın önemli sonuçlarından bir tanesi, eğitim durumunun sorumlulukların paylaşılmasına ilişkin tutumu olduğu kadar, büyük ebeveynlerin rehberlik rollerini de çeşitlendirdiğidir. İlkokul-ortaokul mezunu büyük ebeveynler arasında dini rehberlik rolü daha belirginken, lise-üniversite mezunu büyük ebeveynler bilgi, becerilerini paylaşarak ve çocukların eğitimlerine finansal kaynak sağlayarak danışmanlık etmektedirler. Torunların temel gereksinimlerinin karşılanmasındaki pasif duruşlarına karşılık, rehberlik edilip aile değerlerinin kazandırılması konusunda büyükbabalar, oldukça fazla sorumluluk üstlenmektedirler. Büyükanneler ise tam aksine bu rollerde büyükbabalar kadar etkin değillerdir. Bu bağlamda çalışma dahilinde görüşülen büyükannelerin torunlarının fiziksel bakım ihtiyaçlarına, büyükbabaların da araçsal ihtiyaçlarına cevap verme eğilimi göstererek geleneksel kadınlık ve erkeklik rollerini yerine getirdikleri ifade edilebilir. Hem büyük babaların hem de büyükannelerin üstlendikleri torun bakım sorumluluğuyla toplumsal cinsiyet rollerinin yeniden inşasında etkin bir rol oynadıkları belirtilebilir.

\section{REFERENCES / KAYNAKLAR}

AARP. (2002). The Grandparent Study 2002 Report. Erişim tarihi: 22.02.2019, https://www.aarp.org/relationships/grandparenting/info-2002/aresearch-import-481.html.

Armstrong, M.J. (2005). Grandchildren's influences on grandparents: A resource for integration of older people in New Zealand's aging society. Journal of Intergenerational Relationships, 3(2), 7-21.

Arpacı, F. \& Tezel Şahin, F. (Nisan, 2015). Yaşlı bireylerin yaşlı ve çocuk etkileşimine ilişkin görüşleri. TSA, 19(1), 231-245.

Bates, J.S. (2009). Generative grandfathering: A conceptual framework for nurturing grandchildren. Marriage \& Family Review, 45(4), 331-352.

Baydar, N. \& Brooks-Gunn, J. (1998). Profiles of grandmothers who help care for their grandchildren in the United States. Family Relations, 47(4), 385-393.

Bowers, B.F. \& Myers, B.J. (1999). Grandmothers providing care for grandchildren: Consequences of various levels of caregiving. Family Relations, 48(3), 303-311.

Burgess, A. (2015). Interconnectedness: The grandparents role in childbearing and parenting. International Journal of Childbirth Education, 30(1), 68-73.

Choi, M., Sprang, G. \& Eslinger, J.G. (2016). Grandparents raising grandchildren: A synthetic review and theoretical model for interventions. Family and Community Health, 39(2), 120-128.

Clarke, L. \& Roberts, C. (2003). The meaning of grandparenthood and its contribution to the quality of life of older people. In A.Walker \& C.H.Hennessy (Ed.), Growing older: Quality of life in old age (ss.188-208). England: Open University Press. 
Danielsbacka, M., Tanskanen, A.O. \& Rotkirch, A. (2015). Impact of genetic relatedness and emotional closeness on intergenerational relations. Journal of Marriage and Family, 77(4), 889-907.

Dellmann-Jenkins, M., Hollis, A.H. \& Gordon K.L. (2005). An intergenerational perspective on grandparent roles: views of young parents and middle-age/older adults. Journal of Intergenerational Relationships, 3(1), 3548.

Denham, T.E. \& Smith, C.W. (1989). The influence of grandparents on grandchildren: A review of the literature and resources. Family Relations, 38(3), 345-350.

Gauthier, A. (2002). The role of grandparents. Current Sociology, 50(2), 295-307.

Goodman, C.C. \& Silverstein, M. (2001). Grandmothers who parent their grandchildren. Journal of Family Issues, 22(5), 557-578.

Dunifon, R. \& Bajracharya, A. (2012). The role of grandparents in the lives of youth. Journal of Family Issues, 33(9), 1168-1194.

Griggs, J., Tan, J., Buchanan, A., Attar-Schwartz, S. \& Flouri, E. (2010). They've always been there for me: Grandparental involvement and child well-being. Children \& Society, 24(3), 200-214.

Herlofson, K. \& Hagestad, G.O. (2012). Transformations in the role of grandparents across welfare states. In S.Arber \& V.Timonen (Ed.), Contemporary grandparenting (ss. 27-49). University of Bristol: The Policy Press.

Richard, A. \& Harris, P. (2001). Second time around: A survey of grandparents raising their grandchildren. Adoption and Fostering, 25(3), 67-69.

Kemp, C.L. (2007). Grandparent-grandchild ties. Reflections on continuity and change across three generations. Journal of Family Issues, 28(7), 855-881.

Margolis, R. (2016). The changing demography of grandparenthood. Journal of Marriage and Family, 78, 610622.

Mehta, K.K. \& Thang, L. L. (2012). Introduction: Grandparenthood in Asia. In K. K. Mehta \& L. L. Thang (Ed.), Experiencing Grandparenthood An Asian Perspective (ss.1-19). New York: Springer.

Parsons, T. (1972). Age and sex in the social structure of the United States. P. Prentice-Hall, Inc.

Schmid, W. (2018). Anne baba ve büyükanne büyükbaba olmanın sevinçleri üzerine (T. Bora, Çev.). İstanbul: İletişim Yayıncılık.

Svensson-Dianellou, A., Smith, P.K. \& Mestheneos, E. (2010). Family help by Greek grandparents. Journal of Intergenerational Relationships, 8(3), 249-263.

Timonen, V. \& Arber, S. (2012). A new look at grandparenting. In S.Arber \& V.Timonen (Ed.), Contemporary grandparenting (ss. 1-24). University of Bristol: The Policy Press.

Villar, F., Triado, C., Pinazo-Hernandis, S., Celdran, M. \& Sole, C. (2010). Grandparents and their adolescent grandchildren: Generational stake or generational complaint? A study with dyads in Spain. Journal of Intergenerational Relationships, 8(3), 281-297.

Wang, Y. \& Marcotte, D.E. (2007). Golden years? The labor market effects of caring for grandchildren. Discussion Paper Series, IZA DP No. 2629, 1-38.

Williams, M.N. (2011). The changing roles of grandparents raising grandchildren. Journal of Human Behavior in the Social Environment, 21(8), 948-962.

Xu, L., Silverstein, M. \& Chi, I. (2014). Emotional closeness between grandparents and grandchildren in rural China: The mediating role of the middle generation. Journal of Intergenerational Relationships, 12(3), 226-240. 
$\begin{array}{lrlll}\text { TÜIK.(2017). Evlenme } & \text { istatistikleri. } & \text { Erişim } & \text { tarihi: } & \text { 21.02.2019, }\end{array}$ https://biruni.tuik.gov.tr/medas/?kn=112\&locale=tr

TÜİK. (2017). Eğitim istatistikleri. Erişim tarihi: 21.02.2019, https://biruni.tuik.gov.tr/medas/?kn=130\&locale=tr 